\title{
Land subsidence and aquifer compaction in Montgomery County, Texas, U.S.: 2000-2020
}

\author{
Kuan Wang ${ }^{1}$, Guoquan Wang ${ }^{1 *}\left(\mathbb{D}\right.$, Brendan Cornelison ${ }^{1}$, Hanlin Liu ${ }^{2}$ and Yan Bao ${ }^{3}$
}

\begin{abstract}
Groundwater-withdrawal-induced land subsidence has been a big concern in Montgomery County, Texas, U.S. since the 2000s. As of 2020, approximately half of the entire county is experiencing subsidence over $5 \mathrm{~mm} /$ year. This study aims to investigate ongoing land subsidence in Montgomery County using groundwater-level, extensometer, and GPS datasets. According to this study, land subsidence in Montgomery County since the mid-2000s is primarily contributed by sediment compaction in the Evangeline and Jasper aquifers; the compaction of Jasper aquifer contributes approximately one-third of the land subsidence since the mid-2000s; the pre-consolidation heads of the Chicot, Evangeline, and Jasper aquifers in Montgomery County are close to each other, approximately 15-25 m below mean sea level; the virgin-compaction/head-decline ratio is approximately 1:250 in the Evangeline aquifer and 1:800 in the Jasper aquifer in central and southern Montgomery County. As of 2020, the Jasper groundwater-level altitude is approximately $20-40 \mathrm{~m}$ below the pre-consolidation head in the central and southern Montgomery County; the Evangeline groundwater-level altitude is about $40-60 \mathrm{~m}$ below the pre-consolidation head. Land subsidence will continue to occur as long as the groundwater-level altitude in either the Evangeline or the Jasper aquifer remains below the pre-consolidation head.
\end{abstract}

Keywords: Subsidence, Pumping, GPS, Pre-consolidation head, Virgin-compaction/head-decline ratio

\section{Introduction}

\section{Study area}

Montgomery County is a part of the Houston-The Woodlands-Sugar Land, Texas Metropolitan Statistical Area (MSA), which is often designated as Greater Houston, encompassing nine counties along the Gulf Coast in Southeast Texas with a population of over seven million people at the 2020 census estimates (Fig. 1). Land subsidence has affected the Greater Houston region for nearly a century. As the population has grown outward from Houston to the north and the northwest since the 1990s, groundwater pumping, in turn, land subsidence, follows the same pattern of urban expansion (e.g., Coplin and Galloway 1999; Qu et al. 2015; Turco and Petrov

\footnotetext{
*Correspondence: gwang@uh.edu

${ }^{1}$ Department of Earth and Atmospheric Sciences, University of Houston, Houston 77204, USA

Full list of author information is available at the end of the article
}

2015; Petersen et al. 2020). The Woodlands in Montgomery County has become one of the most affected areas by subsidence in the Greater Houston region since the 2010s (Fig. 1).

Montgomery County comprises approximately $2700 \mathrm{~km}^{2}$ of flat to gently rolling terrain, with elevations ranging from about $40-120 \mathrm{~m}$ above sea level. Groundwater-withdrawal-induced land subsidence was reported in southern Montgomery County in the early 1960s (Gabrysch 1967). Land surface deformation monitoring using Global Positioning System (GPS) in Montgomery County began in the early 2000s. Rapid subsidence up to $20 \mathrm{~mm}$ /year was recorded by GPS in northern Harris County and southern Montgomery County during the 2000s (e.g., Welch 2018; Zhou 2020). The ongoing land subsidence since the mid-2010s is approximately 5-7 $\mathrm{mm}$ /year in central Montgomery County and $8-10 \mathrm{~mm} /$ year in southern Montgomery County. Over half of Montgomery County is 


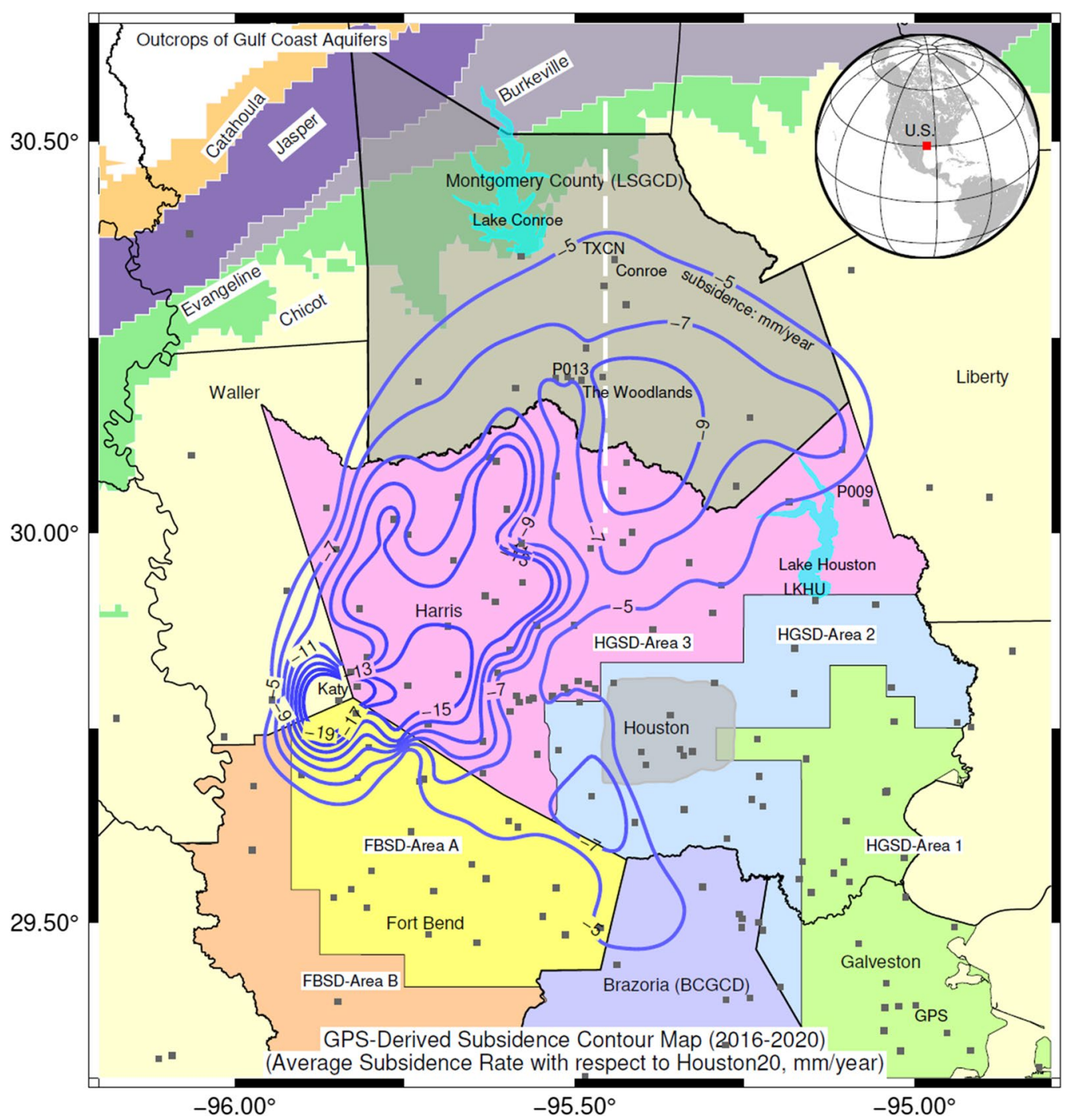

Fig. 1 Map showing the contours of average subsidence rates (2016-2020) derived from over 210 permanent GPS observations (> 3 years) within the Greater Houston region. The gray squares represent GPS sites used for creating the contour map. The subsidence rates are aligned to the Stable Houston Reference Frame (Houston20). The northwest corner of this map displays outcrops of the Gulf Coast Aquifer (Casarez 2020). The color patterns represent the areas regulated by the Harris-Galveston Subsidence District (HGSD: Areas 1, 2, 3), the Fort Bend Subsidence District (FBSD: Areas A and B), the Brazoria County Groundwater Conservation District (BCGCD), and the Lone Star Groundwater Conservation District (LSGCD)

experiencing land subsidence over $5 \mathrm{~mm} /$ year as of 2020 (Fig. 1).

Ground deformation associated with subsidence and faulting has caused frequent damages to residential buildings and public infrastructure in northern Harris County and southern Montgomery County (e.g., Khan et al. 2013; Campbell et al. 2018; Qu et al. 2019). Longterm subsidence also increases the flooding risk (e.g., Miller and Shirzaei 2019), which has a particular concern in low-lying residential areas in southern Montgomery County.

\section{Local aquifers}

In Montgomery County, the principal source of usable groundwater is the Gulf Coast Aquifer, which comprises five subdivisions in and around Montgomery County: from shallowest to deepest, the Chicot aquifer, the Evangeline aquifer, the Burkeville confining unit, the Jasper aquifer, and the Catahoula Sandstone (Baker 1979; Chowdhury and Turco 2006). These subdivisions crop out in northwestern Montgomery County, as depicted in Fig. 1, where the aquifers receive recharge from precipitation and surface water (Kasmarek and Robinson 2004). 
The Chicot aquifer is the youngest of the Gulf Coast Aquifer subdivisions, followed by the Evangeline Aquifer, the Burkeville confining unit, and the Jasper aquifer. The Catahoula sandstone is the oldest of the Gulf Coast Aquifer System. The successively older units crop out progressively further inland at higher elevations (Figs. 1, 2). These aquifers comprise laterally discontinuous gravel, sand, silt, and clay (Baker 1979). The thickness of the Chicot aquifer in Montgomery County varies from less than $100 \mathrm{~m}$ in the north to approximately $200 \mathrm{~m}$ in the south; the thickness of the Evangeline aquifer is approximately $200 \mathrm{~m}$; the thickness of the Burkeville confining system is about $100 \mathrm{~m}$ throughout the county; the thickness of the Jasper aquifer is around 300-500 m (Popkin 1971; Young et al. 2012) (Fig. 2).

\section{Groundwater use and management}

The Chicot, Evangeline, and the upper portion of Jasper aquifers generally contain freshwater throughout the county. The lower part of the Jasper and Catahoula Sandstone contain slightly saline water (brackish water) in the northern and central parts of the county (Popkin 1971).
Figure 3 lists the history of groundwater and surface water use in Montgomery County from 1984 to 2018. The data is from Texas Water Development Board (TWDB) Historical Water Use Estimates Database (http://www.twdb.texas.gov/waterplanning/waterusesu rvey/estimates/index.asp). Groundwater pumping gradually increased with the county's growth in population since the 1980s and reached the maximum in 2011 $\left(\sim 125 \times 10^{6} \mathrm{~m}^{3}\right)$. Total groundwater use increased by a factor of ten from approximately $13 \times 10^{6} \mathrm{~m}^{3}$ in 1984 to $130 \times 10^{6} \mathrm{~m}^{3}$ in 2011 , with the vast majority (over 90\%) of groundwater use going to the municipal sector. The extraordinary groundwater pumping from 2011 to 2013 was resulted by the severe drought occurred during this period in the southern U.S.

The Texas State Legislature established the Lone Star Groundwater Conservation District (LSGCD) in 2001 to regulate groundwater use and control subsidence in Montgomery County. According to LSGCD's pumping data associated with permits, the pumping amount from the Chicot aquifer was approximately $2-3 \%$ of the annual total-pumping during the past 2 decades; the pumping

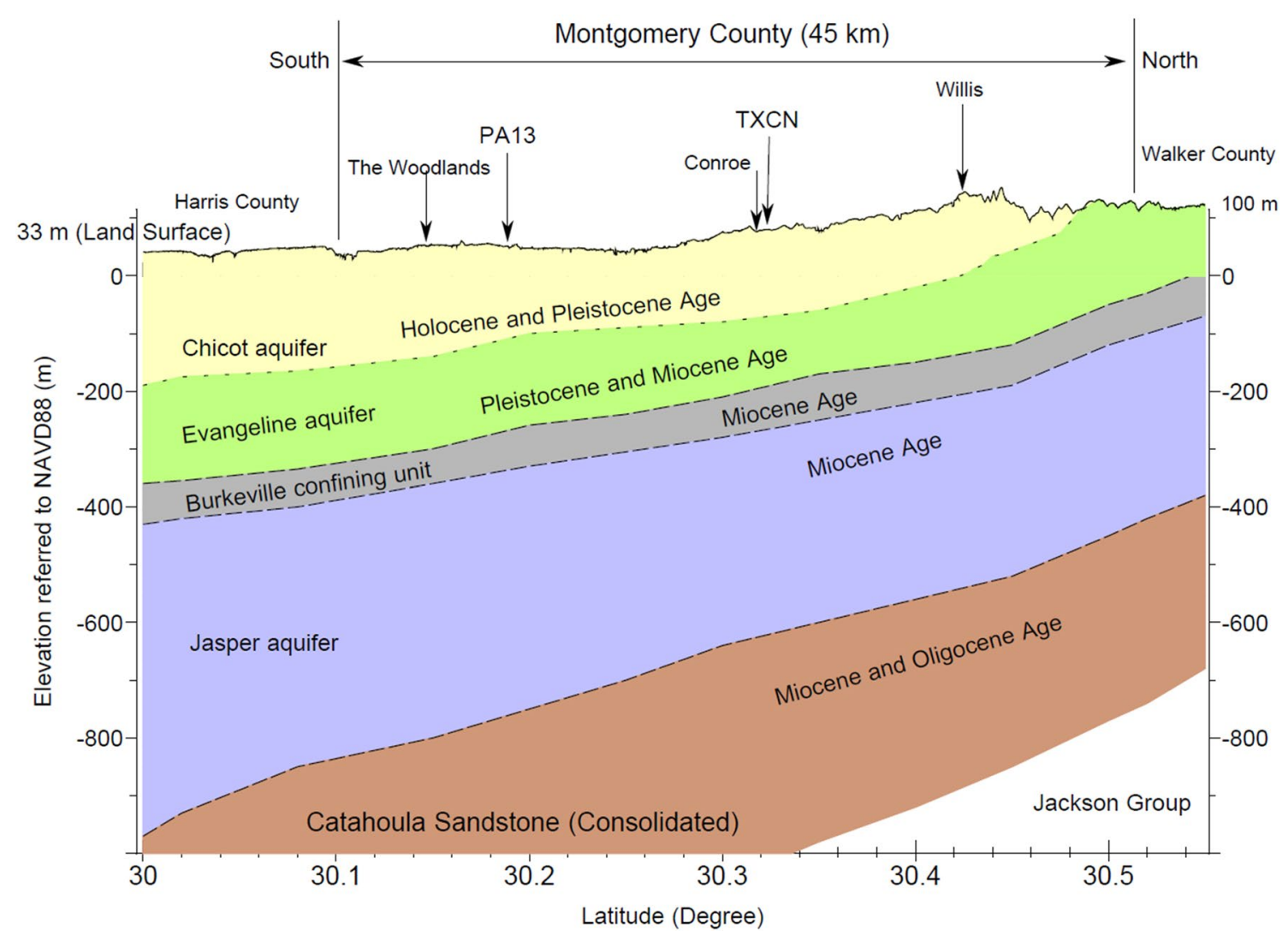

Fig. 2 Generalized hydrogeologic section of the Gulf Coast Aquifers crossing Montgomery County from the south to the north. The extension of the cross-profile is illustrated in Fig. 1 (white line). The depth and thickness information of the aquifers is combined from Popkin (1971), Baker (1979), and Young et al. (2012) 


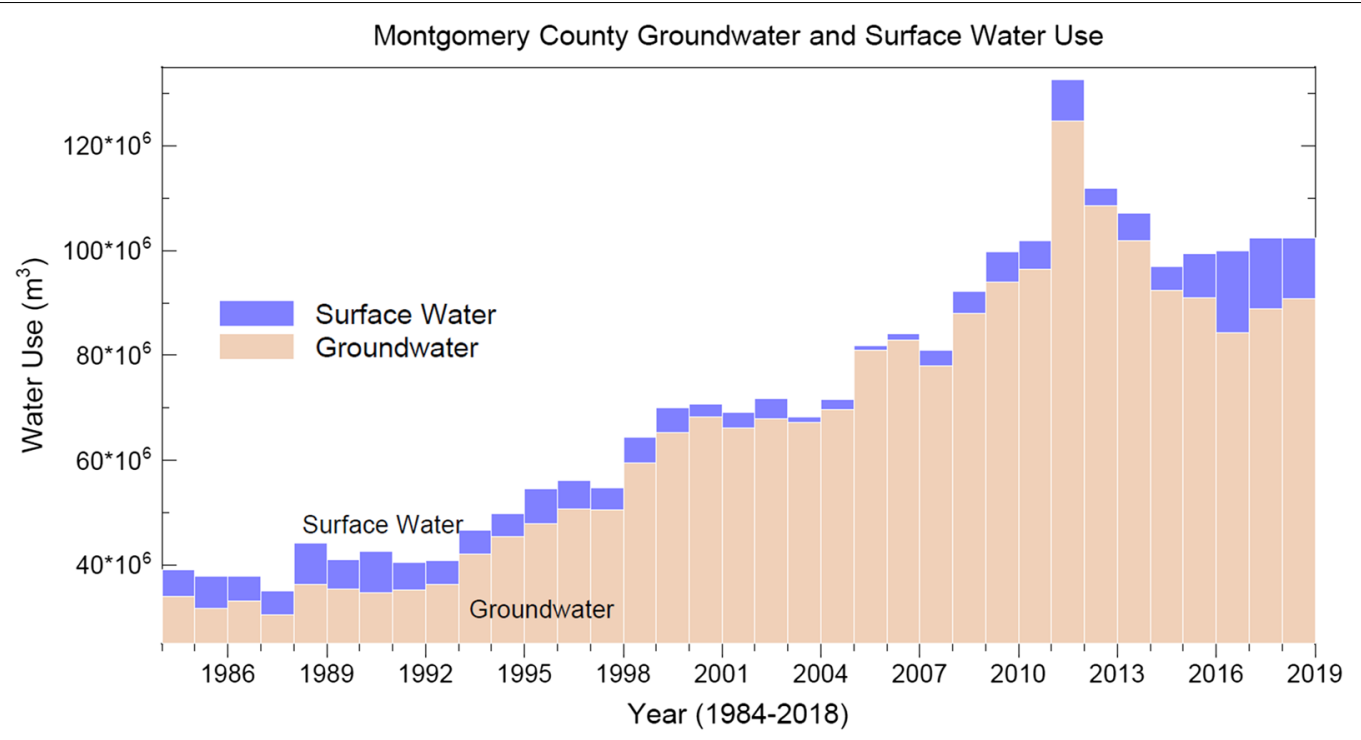

Fig. 3 Groundwater and surface water use in Montgomery County from 1984 to 2018. The water use information is combined from the Texas Water Development Board (TWDB)'s Water Use Database (http://www.twdb.texas.gov/waterplanning/waterusesurvey/estimates/index.asp)

amount from the Evangeline aquifer was approximately $50-55 \%$ of the annual total-pumping, and the pumping amount from the Jasper aquifer was approximately $40-45 \%$ of the annual total-pumping (Thornhill and Keester 2020).

LSGCD has been continuously improving its Management Plan since it was created in 2001. The original management plan was adopted on October 14, 2003, then later amended and re-adopted in 2008, in 2013, and most recently in 2020. The 2013 management plan mandated large-volume groundwater users, such as the City of Conroe and large water utilities, to reduce their groundwater production by thirty percent (30\%) of their Total Qualifying Demand (approximately their total water use amount in 2009) by January 1, 2016 (LSGCD 2013). As part of a groundwater usage reduction plan, the San Jacinto River Authority built a surface water treatment facility in Conroe (https://www.sjra.net/grp/treatment-plant). It began to transfer treated surface water from Lake Conroe to the central and southern county areas in 2015. Before 2015 , groundwater use was about $95 \%$ of the total water in Montgomery County. As of 2018, the groundwater use has reduced to approximately $85 \%$ of the total water use (Fig. 3).

The reduction in groundwater pumping since the mid2010s has resulted in county-wide groundwater-level recovery in both the Evangeline and Jasper aquifers. Figure 4 illustrates the groundwater-level contour lines showing Jasper groundwater changes during 5 years before and after 2015. The 2010-2014 Jasper groundwater-level-change contours reveal that the groundwater level declined throughout the county before 2015, with the most rapid decline in southern Montgomery County. The decline rate was about $3 \mathrm{~m} /$ year in the area between The Woodlands and Conroe. The 2015-2019 Jasper groundwater-level-change contours reveal that groundwater level was rising throughout the entire county since 2015. The rising rate in northern Conroe and eastern The Woodlands was about $2 \mathrm{~m} /$ year.

In August 2015, the City of Conroe and seven other utility providers filed a lawsuit against the LSGCD over the district's regulations of groundwater usage. On May 17, 2019, the 284th District Court in Montgomery County signed a Final Judgment declaring that the large-volume groundwater user rules under the LSGCD's Regulatory Plan were adopted without legal authority and consequently are unenforceable. LSGCD adjusted its groundwater regulation rules accordingly in 2020. The LSGCD's 2020 Regulatory Plan no longer requires the large-volume groundwater users to follow the previous requirement of reducing their groundwater pumping by thirty percent of their Total Qualifying Demand (LSGCD 2020).

\section{Motivation}

The Harris-Galveston Subsidence District (HGSD), United State Geological Survey (USGS), LSGCD, and several other local agencies have been conducting groundwater-level and subsidence monitoring for over 4 decades in northern Harris County and southern Montgomery County. Groundwater pumping in northern Harris County is primarily from the Chicot and Evangeline 


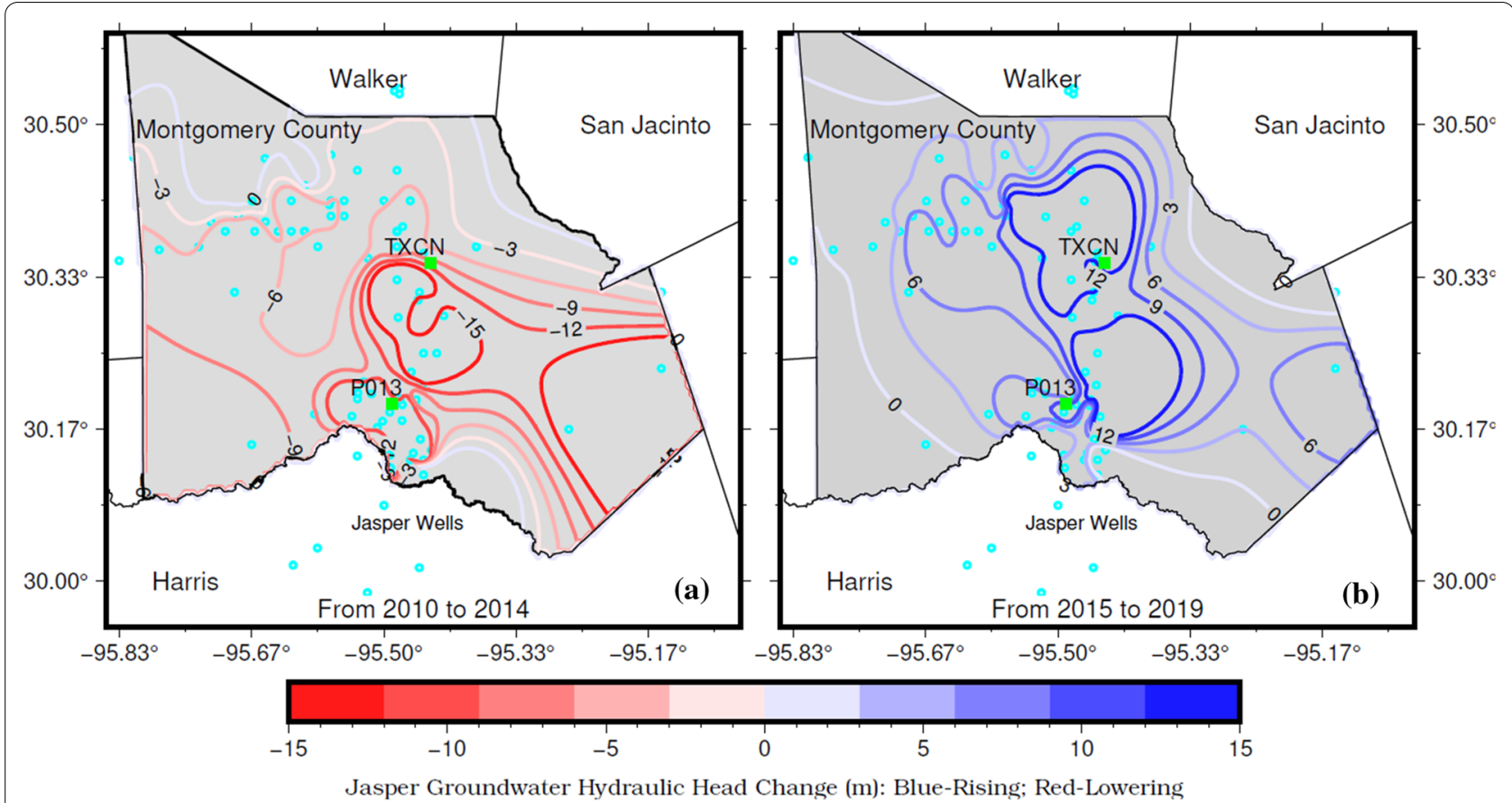

Fig. 4 Jasper groundwater-level changes in Montgomery County. a The change of groundwater altitude during the 5-year period from the beginning of 2010 to the end of 2014 ; $\mathbf{b}$ the change of groundwater altitude in meters during the 5 -year period from the beginning of 2015 to the end of 2019. The color bar indicates the magnitude of groundwater altitude changes in meters

aquifers (Greuter and Petersen 2021). The correlation between subsidence and groundwater level changes and the compressibility of the Chicot and Evangeline aquifers in Harris County have been deliberately investigated by USGS (e.g., Kasmarek et al. 2016; Shah et al. 2018; Braun and Ramage 2020). One important conclusion is that the groundwater-withdrawal-induced sediment compaction has not extended to the Jasper aquifer, at least in central and southern Harris County. In general, the compaction is limited within the Chicot aquifer and the top portion of the Evangeline aquifer, approximately within $600 \mathrm{~m}$ to the ground surface (Yu et al. 2014). However, groundwater pumping in Montgomery County is primarily from the Evangeline and Jasper aquifers. The percentage of Jasper groundwater pumping among total groundwater pumping has been gradually increasing since the 2010s. The upper portion of the Jasper aquifer is designated as the primary target for fresh water in northern Harris County and southern Montgomery County, and the lower portion of the Jasper aquifer is designated as potential sources of brackish groundwater (e.g., Young et al. 2016; Kelley et al. 2018). The confined zones of the Jasper and Evangeline aquifers retain the highest risk for future subsidence from pumping (Furnans et al. 2018). There is a general lack of understanding regarding the compressibility and potential compaction for the Jasper Aquifer. Following questions have been raised in both the research and groundwater management communities: (1) has aquifer compaction extended to Jasper aquifer in Montgomery County? (2) If yes, how much is the contribution of the Jasper aquifer to the present land subsidence? (3) What is the compressibility of the Jasper aquifer? This investigation aims to address these questions using publicly-available groundwater-level, extensometer, and GPS datasets.

\section{Data and methodology GPS data}

The Greater Houston region is one of the earliest urban areas to employ GPS technology for land subsidence and fault monitoring. As of 2021, HGSD and the University of Houston (UH) have integrated over 240 permanent GPS stations into their routine GPS data processing for land subsidence monitoring in the Greater Houston region, approximately $2.2 \times 10^{4} \mathrm{~km}^{2}$ (Fig. 1). There are 14 permanent GPS stations with over 5 -year observational history in Montgomery County as of 2020 (Fig. 5). HGSD installed a new permanent GPS station, YORS, in the south of The Woodlands in 2020, in cooperation with The Woodlands Water Agency and the San Jacinto River Authority. P013, P012, P068, P070, P071, and P073 are campaign-style permanent GPS stations, also known as Port-A-Measure (PAM) stations, operated by HGSD in cooperation with LSGCD. These 


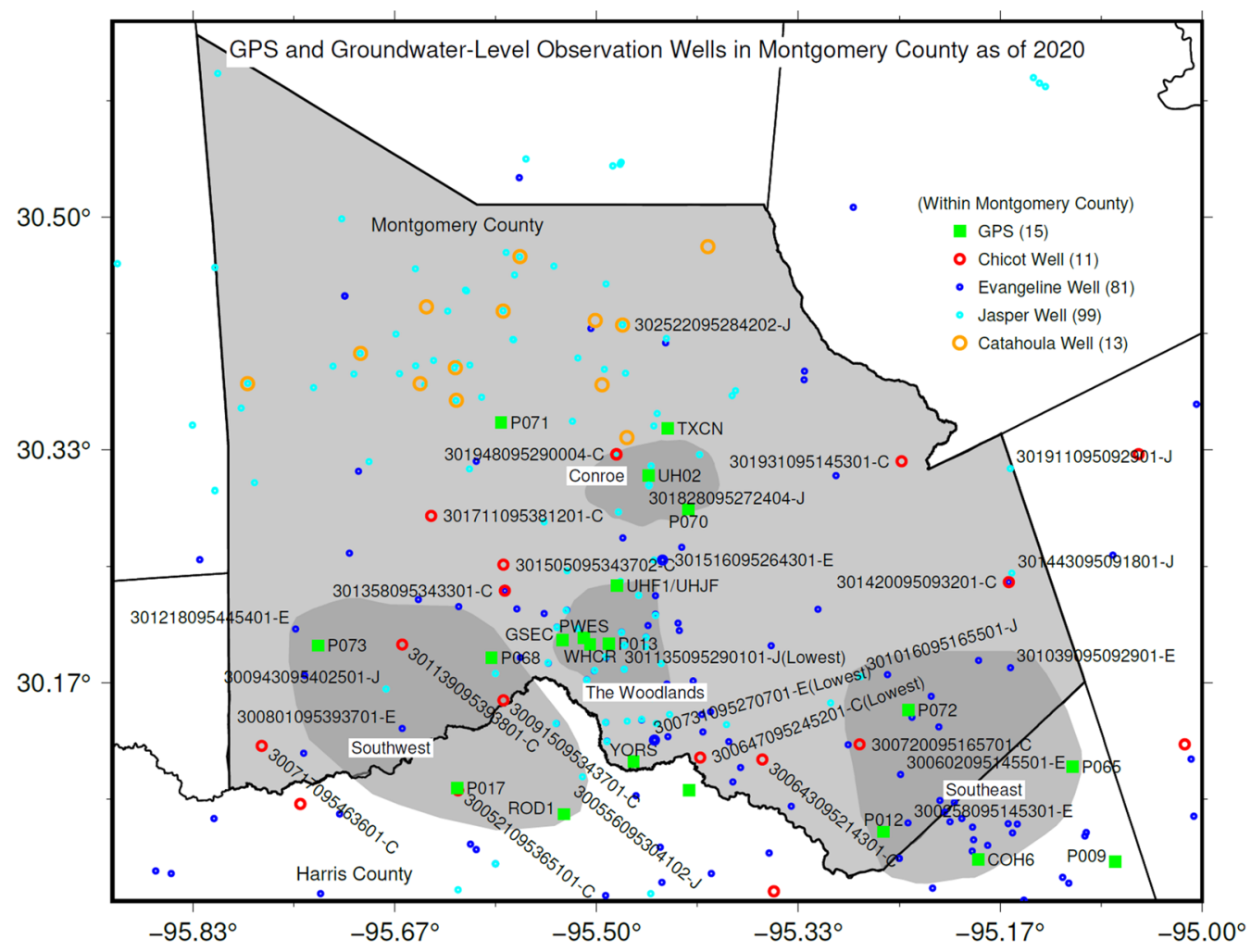

Fig. 5 Map showing the locations of GPS and groundwater-level observation wells in Montgomery County and adjacent areas. A letter is added to the end of USGS well ID. "C" represents a Chicot well. "E" represents an Evangeline well. "J" represents a Jasper well

PAM stations were designed for periodically repeated long-term monitoring. On average, PAM data was collected for 1 week every month before 2005 and 1 week per 2 months after 2005. TXCN is a Continuously Operating Reference Station (CORS) operated by the Texas Department of Transportation (TxDOT, https:// www.txdot.gov/inside-txdot/division/informationtechnology/gps.html). UH02 is a CORS jointly operated by UH and SmartNet (https://www.smartnetna.com). UHF1, UHJF, PWES, GSEC, and WHCR are continuous GPS stations operated by UH. UHF1 and UHJF are closely-spaced. Only the observations at UHF1 are used in this study. The detailed information of these GPS stations is listed in Table 1. The UH GPS network consists of over 70 permanent GPS stations in the Houston metropolitan region (Wang et al. 2015). Four GPS stations (P017, ROD1, COH6, P065) located in northern Harris County, adjacent to Montgomery County, are also investigated in this study. P017 and P065 are PAM stations. COH6 is a CORS jointly operated by the City of Houston and HGSD. ROD1 is a CORS operated by RODS Surveying Inc. (http://www.rods.cc). Based on the distribution of GPS stations, we have investigated the land subsidence in the following four areas: The
Woodlands, the City of Conroe, the Northeast, and the Southwest (Fig. 5).

The raw data of PAM stations are archived at HGSD. The raw data of UH GPS are archived at UH and UNAVCO. CORS raw data are archived at National Geodetic Survey (NGS) at the National Oceanic and Atmospheric Administration (NOAA). GPS-derived subsidence time series are open to the public through HGSD. The subsidence time series are obtained by differencing the GPS-derived ellipsoidal heights with respect to the Stable Houston Reference Frame 2020, abbreviated as Houston20. Houston 20 is realized by long-term GPS observations at 25 Continuously Operating Reference Stations (CORS) located outside of the greater Houston region, where no considerable groundwater-withdrawalinduced subsidence has occurred since the 1990s (Agudelo et al. 2020).

The stability of Houston 20 is at a level of $0.3 \mathrm{~mm} /$ year in each horizontal direction (NS: North-South; EW: East-West) and $0.8 \mathrm{~mm} /$ year in the vertical direction. A detailed GPS data process strategy is addressed in Wang et al. (2013) and Kearns et al. (2019). The accuracy (root mean square error) of daily vertical-positions derived from GPS observations is 6-8 $\mathrm{mm}$ (Wang et al. 2017). 
Table 1 Permanent GPS stations in Montgomery County, Texas

\begin{tabular}{|c|c|c|c|c|c|c|c|c|c|c|}
\hline \multirow[t]{2}{*}{ GPS } & \multicolumn{2}{|l|}{ Location } & \multicolumn{4}{|c|}{ Observational history } & \multicolumn{3}{|c|}{$\begin{array}{l}\text { Vertical displacement (negative indicates } \\
\text { subsidence) }\end{array}$} & \multirow[t]{2}{*}{ Raw data archiving } \\
\hline & Latitude & Longitude & Start & End & Years & Days & Total $^{\mathrm{a}}(\mathrm{cm})$ & $\begin{array}{l}5 \text {-year rate } \\
(\mathrm{cm} / \text { year })^{\mathrm{b}}\end{array}$ & Operator & \\
\hline P012 & -95.263 & 30.060 & 2000.9 & 2020.4 & 19.5 & 1331 & -12.2 & -0.6 & HGSD & HGSD \\
\hline P013 & -95.490 & 30.195 & 2000.9 & 2021.2 & 20.3 & 1259 & -25.2 & -1.4 & HGSD & HGSD \\
\hline P068 & -95.587 & 30.185 & 2011.8 & 2021.2 & 9.4 & 545 & -8.9 & -1.0 & HGSD & HGSD \\
\hline P069 & -95.459 & 30.199 & 2011.7 & 2021.2 & 9.4 & 556 & -10.6 & -1.1 & HGSD & HGSD \\
\hline P070 & -95.424 & 30.291 & 2011.8 & 2021.2 & 9.5 & 493 & -4.9 & -0.5 & HGSD & HGSD \\
\hline P071 & -95.579 & 30.353 & 2011.8 & 2021.2 & 9.5 & 553 & -3.8 & -0.4 & HGSD & HGSD \\
\hline P072 & -95.242 & 30.147 & 2012.0 & 2021.2 & 9.2 & 398 & -7.5 & -0.7 & HGSD & HGSD \\
\hline $\mathrm{YORS}^{\mathrm{C}}$ & -95.469 & 30.110 & 2020.8 & 2021.2 & 0.3 & 126 & & & HGSD & HGSD \\
\hline TXCN & -95.441 & 30.349 & 2005.6 & 2021.3 & 15.7 & 5707 & -17.2 & -1.2 & TxDOT & NGS \\
\hline UH02 & -95.457 & 30.315 & 2015.0 & 2021.2 & 6.2 & 2114 & -3.6 & -0.6 & UH\&SmartNet & UH\&UNAVCO \\
\hline UHF1/UHJF & -95.483 & 30.236 & 2014.4 & 2020.7 & 6.3 & 2258 & -5.9 & -0.6 & UH & UH\&UNAVCO \\
\hline WHCR & -95.505 & 30.194 & 2014.8 & 2021.3 & 6.5 & 2363 & -3.7 & -0.6 & UH & UH\&UNAVCO \\
\hline PWES & -95.511 & 30.199 & 2015.2 & 2021.3 & 6.0 & 2205 & -6.1 & -0.9 & UH & UH\&UNAVCO \\
\hline GSEC & -95.528 & 30.197 & 2015.8 & 2021.3 & 5.5 & 2008 & -2.8 & -0.7 & UH & UH\&UNAVCO \\
\hline
\end{tabular}

${ }^{a}$ Total subsidence represents the total vertical displacement over the entire history of each GPS station

${ }^{b}$ The 5-year subsidence rate represents the linear trend of the subsidence time series from 2016 to 2020

c YORS is a new station installed in 2020. http://www.twdb.texas.gov/waterplanning/waterusesurvey/estimates/index.asp

For subsidence studies, users often pay more attention to the accuracy or confidence of the estimated subsidence rates (linear trends) rather than the accuracy of individual positions. In general, longer GPS observations would result in higher accuracy for estimating subsidence rates. Wang (2021) provides an empirical formula for estimating the $95 \%$ confidence interval $(95 \% \mathrm{CI}$, also called accuracy) of GPS-derived vertical site velocities:

$$
b_{95 \% C I}=5.2 \times \frac{1}{T^{1.25}},
$$

where $T$ is the year range of the time series in decimal years and $b_{95 \% C I}$ is the $95 \%$ confidence interval of the linear trend $(b)$ in millimeters per year. According to the empirical formula, 4-year continuous GPS observations would result in a subsidence-rate estimate with an accuracy $(95 \% \mathrm{CI})$ of $1 \mathrm{~mm} /$ year; 7 -year continuous observations would result in a subsidence-rate estimate with an accuracy $(95 \% \mathrm{CI})$ of $0.5 \mathrm{~mm}$ /year.

The realization of regional reference frames has excluded or minimized the regional "common" ground movements, including the secular plate movement of the North American Plate with respect to the International GNSS Service (IGS) reference frames, glacial isostatic adjustment (GIA), natural consolidation of young sediments, surface mass loading associated with atmosphere and ocean, and other regional-scale minor secular effects (e.g., Wang et al. 2020; Zhou et al. 2021). So, GPS-derived subsidence with respect to Houston 20 is principally caused by local-scale anthropogenic processes, primarily the aquifer compaction associated with groundwater withdrawals. According to the report of Texas Drilling (http://www.texas-drill ing.com/montgomery-county), the oil and gas production in Montgomery County has reduced significantly since the 2000s. So far, the exact magnitude of the contribution of hydrocarbon production is still uncertain and remains an important issue for future investigations.

GPS-derived heights are the distances above a smooth ellipsoid surface, which are called ellipsoidal heights. Conventional subsidence obtained from leveling survey is a physical quantity that refers to the surface of the geoid, called orthometric heights in surveying engineering. Ellipsoidal heights and orthometric heights are essentially different. The former is a geometric quantity, while the latter is a physical-based quantity. According to Wang and Soler (2014), ellipsoid heights and orthometric heights would result in the same practical subsidence measurements during the same time span. Accordingly, the subsidence values provided in this study can be regarded as having the same physical meaning as the conventional subsidence measurements obtained from leveling surveys. 


\section{Groundwater data}

Groundwater levels in Montgomery County, Texas, have been periodically measured since the 1940s. Records of these measurements, known as groundwater data or well data, are routinely published by the TWDB and USGS. The groundwater-level observation data used for this study are downloaded from the USGS National Water Information System (NWIS) (https://waterdata.usgs.gov/ nwis) (Ramage 2020). Groundwater-level data collection methods, data quality, and the status of groundwater levels are addressed in the most recent USGS Scientific Investigations Report 2020-5089 (Braun and Ramage 2020). As of 2020, the USGS groundwater datasets comprise 11 Chicot wells, 81 Evangeline wells, 99 Jasper wells, and 13 Catahoula wells in Montgomery County (Fig. 5).

\section{The Chicot groundwater level}

Figure 6 depicts the groundwater levels recorded by these 11 Chicot wells in Montgomery County during the past 3 decades. In this article, the groundwater-level altitudes are aligned to the height with respect to the North
American Vertical Datum of 1988 (NAVD88). Since the altitude of the mean sea level is approximately equivalent to zero with respect to NAVD88, the NAVD88 altitude is also referred to as mean sea level or simply sea level in practice. In this article, the groundwater-level altitudes below mean sea level and above mean sea level are hereafter referred to as negative and positive, respectively. For example, the groundwater-level altitude at $40 \mathrm{~m}$ below sea level is abbreviated as $-40 \mathrm{~m}$; the groundwater-level altitude at $40 \mathrm{~m}$ above sea level is abbreviated as $40 \mathrm{~m}$.

The earliest Chicot groundwater-level measurements are available back to the 1980s. In general, the Chicot groundwater-level altitude at each well was stable during the past 3-4 decades and above the pre-consolidation head of the Chicot aquifer (Fig. 6). Determination of the Chicot pre-consolidation will be explained in the following sections. There is a general trend that the Chicot groundwater level declines from the north to the south. The stability of the Chicot groundwater levels can be explained by the fact that groundwater pumping in the Chicot aquifer is minor in Montgomery County, at least

Chicot Groundwater Levels in Montgomery County

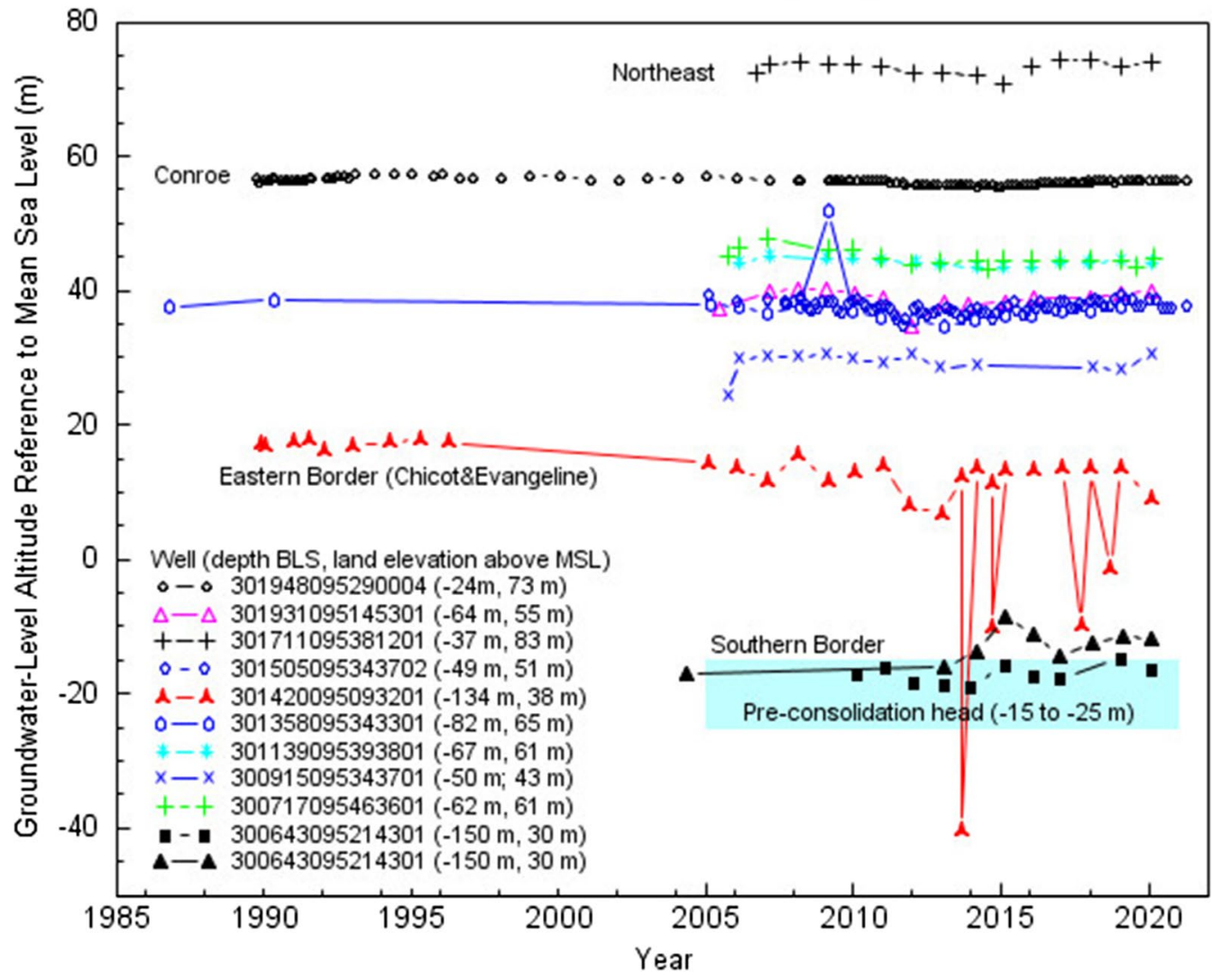

Fig. 6 Groundwater levels in 11 wells completed in the Chicot aquifer in Montgomery County. In the legend, "30194809529004 (- 24 m, 73 m)" indicates USGS well number, well depth below land surface (BLS), and the elevation of land surface reference to mean sea level (MSL). The locations of these wells are marked in Fig. 5 
during the past 2 decades. As mentioned earlier, annual pumping volumes from the Chicot aquifer are approximately $2-3 \%$ of the annual total pumping in Montgomery County since the 2000s. The highest pumping rates from the Chicot aquifer are in The Woodlands area. It is unlikely that the compaction of the Chicot aquifer could remarkably contribute to the ongoing land subsidence (total compaction).

\section{Evangeline and Jasper groundwater levels}

Groundwater-level monitoring in Montgomery County began as early as the 1940s in the Jasper aquifer and the 1960s in the Evangeline aquifer. Figure 7 illustrates the long-history groundwater-level changes in the Chicot aquifer (1989-2020), the Evangeline aquifer (1964-2020), and the Jasper aquifer (1956-2020). Groundwater-level changes at three wells with the lowest altitudes as of 2020 in the Chicot, Evangeline, and Jasper aquifer are also illustrated in Fig. 7. The locations of these wells are plotted in Fig. 5. The Jasper groundwater level in Conroe (USGS ID: 301828095272404, completed $373 \mathrm{~m}$ below land surface) was about $60 \mathrm{~m}$ in the $1960 \mathrm{~s}$ and started to decline since the 1970s and reached the lowest altitude $(-50 \mathrm{~m})$ in the early $2010 \mathrm{~s}$, then began to rise in the mid2010s as a result of the groundwater regulations enforced by LSGCD. The Evangeline groundwater level in the upper Woodlands area (USGS ID: 301516095264301, terminated $214 \mathrm{~m}$ below land surface) followed a similar pattern with the Jasper groundwater level. As of 2020, the lowest groundwater-level altitudes in the Chicot, Evangeline, and Jasper aquifers are $-10 \mathrm{~m},-80 \mathrm{~m}$, and $-60 \mathrm{~m}$, respectively, in southern Montgomery County (Fig. 7).

Figure 8 depicts the contours of groundwater-level altitudes as of the beginning of 2020 in the Evangeline and Jasper aquifers in Montgomery County. The base contour line $(-15 \mathrm{~m})$ represents the pre-consolidation head of each aquifer. The Jasper pre-consolidation-head is coincident with the $5-\mathrm{mm}$ /year subsidence contour. The Jasper

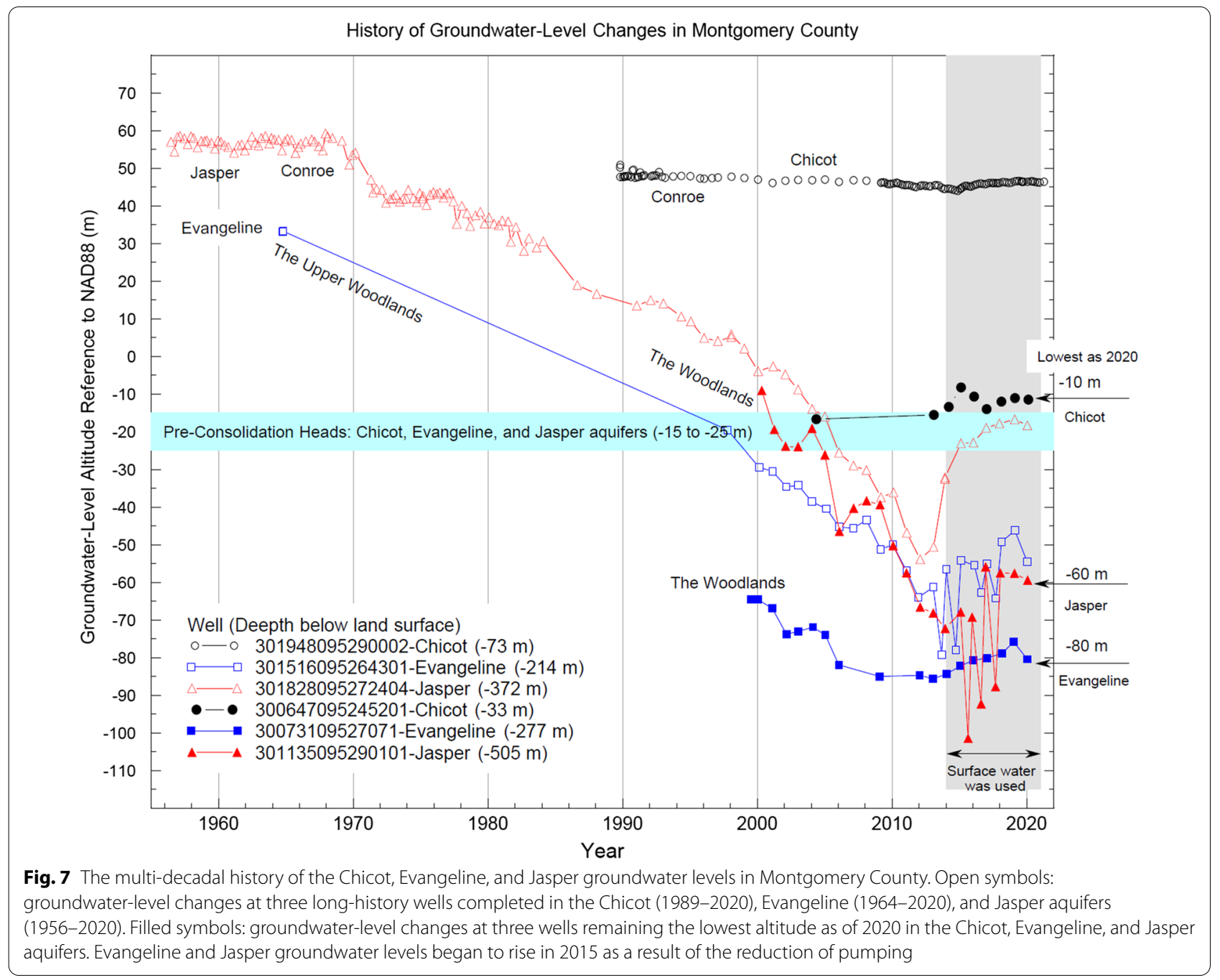




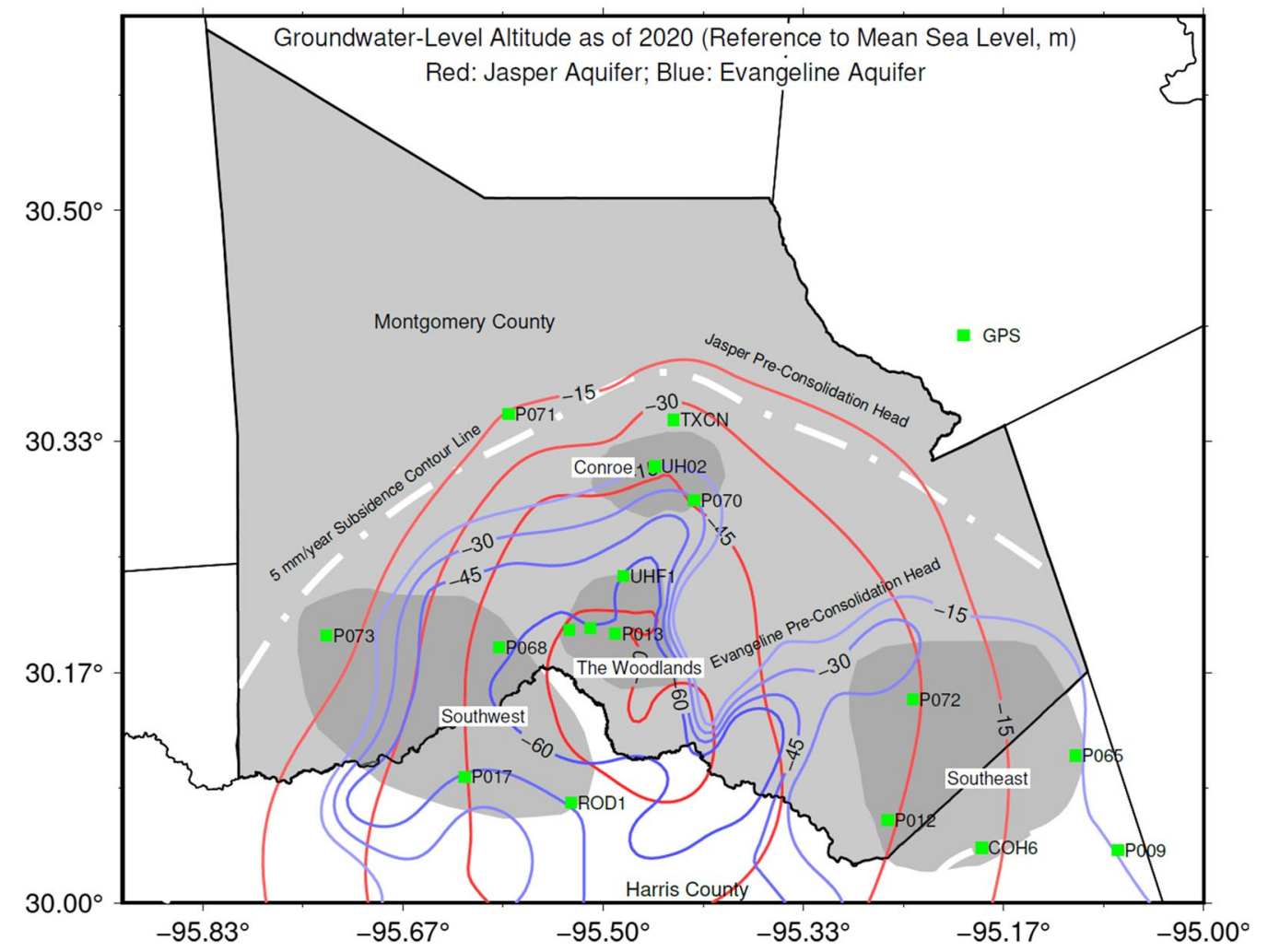

Fig. 8 Evangeline (blue) and Jasper (red) groundwater-level contours as of the beginning of 2020 in Montgomery County. Groundwater-level altitudes are referenced to the mean sea level (zero meters) defined by the North American Vertical Datum of 1988 (NAVD88). The base contour lines $(-15 \mathrm{~m})$ represent the pre-consolidation heads in the Evangeline aquifer (blue) and the Jasper aquifer (red). The white dashed line represents the $5 \mathrm{~mm} /$ year subsidence-contour-line illustrated in Fig. 1

groundwater-level altitude in central and southern Montgomery County, approximately half of the entire county area, is below the pre-consolidation head. A groundwater decline bowl is occurring in The Woodlands area within both the Evangeline and Jasper aquifers. The Jasper groundwater-level altitudes are about $-50 \mathrm{~m}$ to $-70 \mathrm{~m}$ in The Woodlands area, and the Evangeline groundwaterlevel altitude are about from -60 to $-80 \mathrm{~m}$.

\section{Groundwater levels in Burkeville confining unit and Catahoula sandstone}

The Burkeville confining unit consists primarily of clay, which restricts the water flow from the Evangeline aquifer to the Jasper aquifer. There are no groundwater-level measurements in the Burkeville confining unit in Montgomery County before 2020. According to the pumping data from LSGCD, the pumping amount from the Burkeville confining unit is below $1 \%$ of the annual total-pumping in Montgomery County. GPS and extensometer measurements at the Lake Houston site suggest no considerable groundwater-level changes in the Burkeville confining unit during the past 4 decades.
The Lake Houston site is approximately $17 \mathrm{~km}$ south of Montgomery County. Groundwater levels at the Lake Houston site will be addressed in the next section. Since there is little groundwater pumping from the Burkeville confining unit and the groundwater level remained stable during the past decades, no considerable compaction associated with groundwater pumping is expected in this unit.

The pumping from the Catahoula sandstone started in the early 2010s and gradually increased. As of 2018, the pumping amount from the Catahoula sandstone was below 5\% of the annual total-pumping in Montgomery County (Thornhill and Keester 2020). USGS began to monitor groundwater-level in the Catahoula sandstone in 2011. There are 13 groundwater-level observation wells in northern Montgomery County (Fig. 5). Figure 9 illustrates the history of Catahoula groundwater levels during the 2010s measured at these 13 wells. In general, the Catahoula groundwater level has been declining with an average rate of approximately $1.5 \mathrm{~m} /$ year during the 2010s. Since the Catahoula sandstone primarily comprises consolidated sediments in Miocene and Oligocene, 


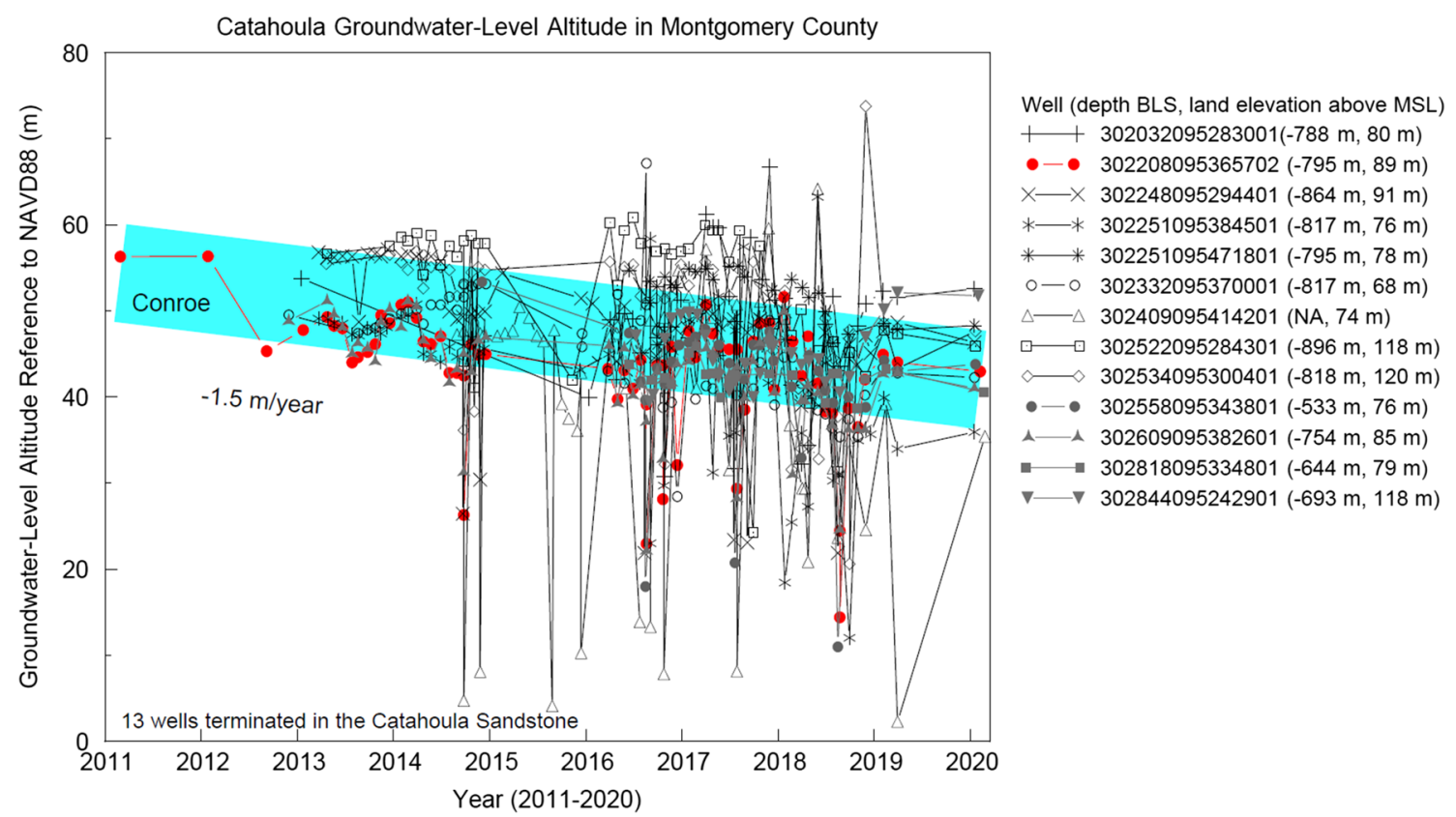

Fig. 9 Groundwater-level changes in the Catahoula sandstone in northern Montgomery County recorded at 13 wells. The locations of these wells are marked in Fig. 5

no considerable compaction associated with groundwater pumping is expected.

\section{Results}

\section{Observations at the Lake Houston site}

In general, GPS-derived subsidence represents the total compaction of unconsolidated and semi-consolidated sediments below the land surface. The compaction within a specific aquifer is often challenging to ascertain using GPS data alone. Combining GPS and long-term borehole extensometer (compaction recorder) datasets may provide compaction information within specific aquifers (e.g., Yu et al. 2014; Liu et al. 2019a, b). Unfortunately, there are no extensometers in Montgomery County. As of 2020, USGS and HGSD operate 14 borehole extensometers within the greater Houston region. The closest extensometer to Montgomery County is located at Lake Houston, Harris County, approximately $17 \mathrm{~km}$ to the south boundary of Montgomery County (Fig. 1). The extensometer measurements (1980-2020) are provided by USGS (Ramage and Shah 2019). Land surface elevation at this site is approximately $16 \mathrm{~m}$ above mean sea level.

The extensometer borehole at Lake Houston was terminated at the top of the Burkeville confining unit, $591 \mathrm{~m}$ below the land surface (Fig. 10a). Six groundwater observation wells were also installed adjacent to the extensometer site (Fig. 10b). Two wells were terminated in the Chicot aquifer; three wells were completed at different depths of the Evangeline aquifer, and one deep well was terminated within the top portion of the Jasper aquifer. The borehole of the extensometer was screened at the bottom. The screen allows groundwater to flow in and out. Thus, the extensometer borehole (out case) also works as a deep groundwater well measuring the groundwater hydraulic head within the top portion of the Burkeville confining unit. HGSD installed a GPS (LKHU) antenna on the top of the inner pole in 1993 with the purpose of providing a stable reference for regional land subsidence monitoring. The inner pole was anchored on the top of the Burkeville confining unit $591 \mathrm{~m}$ below the land surface (Fig. 10b). A permanent GPS (P009) was installed adjacent to Lake Houston in 1999 (see Fig. 1 for the location). The linear distance between P009 and LKHU is $15 \mathrm{~km}$.

\section{Evangeline compaction}

Figure 11a depicts the Lake Houston extensometer and GPS (LKHU) measurements during the past 4 decades. The extensometer measured the total compaction of sediments from the land surface to the bottom of the Evangeline aquifer. The average compaction rate was $11.8 \mathrm{~mm} /$ year during the $1980 \mathrm{~s}$, reduced to $3.8 \mathrm{~mm} /$ year during the $1990 \mathrm{~s}$, and further reduced to approximately $1.3 \mathrm{~mm} /$ year during the 2000s. The GPS measurements (LKHU) on the top of the inner pole indicate 

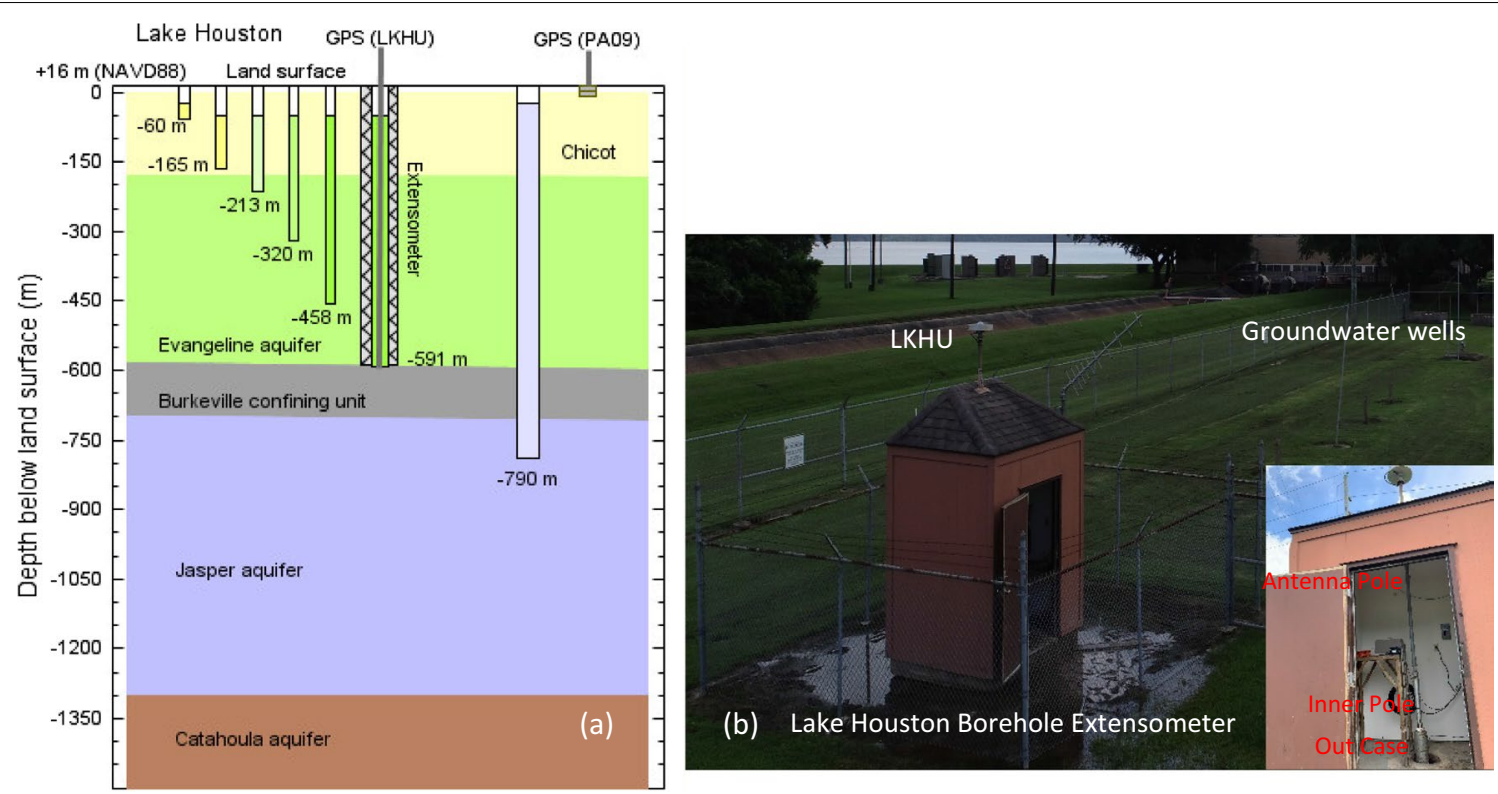

Fig. 10 a A sketch showing the depths of groundwater wells at the Lake Houston site; $\mathbf{b}$ a site photo showing extensometer, GPS, and groundwater wells at the Lake Houston site. The GPS antenna (TXCN) is mounted on the top of the inner pole of the extensometer, which is anchored at the top of the Burkeville confining unit, $591 \mathrm{~m}$ below the land surface

no considerable vertical movements during the entire history from 1993 to 2020. That is, no groundwaterwithdrawal-induced aquifer compaction occurred within the Burkeville confining unit and the Jasper aquifer at this site.

GPS-derived subsidence time series at P009 indicates that the ongoing land subsidence (total compaction) rate in this area has been about $1.8 \mathrm{~mm}$ /year since the 2000s. There are tall trees around P009; therefore, the scatters of the subsidence time series at P009 are remarkably larger than the scatters at other GPS sites. According to the empirical formula (Eq. 1) for estimating the accuracy $(95 \% \mathrm{CI})$ of GPS-derived vertical site velocities, the two-decadal observations (1999-2020) would be long enough to secure submillimeter-peryear accuracy for estimating an overall linear trend (subsidence rate) (Wang 2021). The extensometer data indicates that the average subsidence rate during this period (1999-2020) is approximately $1.3 \mathrm{~mm} /$ year. According to an analysis of co-located and closelyspaced daily-GPS and monthly-extensometer measurements at Addicks in northwestern Houston (Wang et al. 2014), the root-mean-square (RMS) accuracy of the monthly-extensometer measurements is a few millimeters. The accuracy $(95 \% \mathrm{CI})$ of the compaction rate derived from the 20-year monthly-extensometer data (1999-2020) is certainly below $1 \mathrm{~mm} /$ year. Considering the uncertainty of both datasets, the subsidence rates derived from GPS and extensometer datasets agree reasonably well $(-1.3 \mathrm{~mm} /$ year vs. $-1.8 \mathrm{~mm} /$ year $)$, which also suggests no considerable compaction below the Evangeline aquifer.

Figure 11b illustrates the groundwater levels recorded at these seven groundwater-level observation wells. The deep Chicot well (USGS ID: 295451095083901, 165 m below land surface) shows a consistent groundwaterlevel change pattern with these Evangeline groundwater levels. It is likely that the groundwater level in this well was dominated by the groundwater-level change in the Evangeline aquifer. This implies that the interface between the Chicot and the Evangeline aquifers at this site is close to $165 \mathrm{~m}$ below the land surface. The units that make up the Chicot and Evangeline aquifers are similar in lithology and are difficult to differentiate (Baker 1979). The Chicot and Evangeline aquifers are hydraulically connected, which allows groundwater to flow between them. The shallow Chicot well (USGS ID: 295449095083401, $60 \mathrm{~m}$ below land surface) shows a slight rise $(0.2 \mathrm{~m} /$ year $)$ of the Chicot groundwater level from approximately $-18 \mathrm{~m}$ in 1980 to $-10 \mathrm{~m}$ in 2020 . The Chicot groundwater level has been above the preconsolidation head since the 1990s. It is unlikely that the Chicot aquifer could considerably contribute to the land surface subsidence since the 1990s. Thus, the total aquifer compaction recorded by the extensometer during the past 3 decades is solely contributed by the compaction of the Evangeline aquifer. 

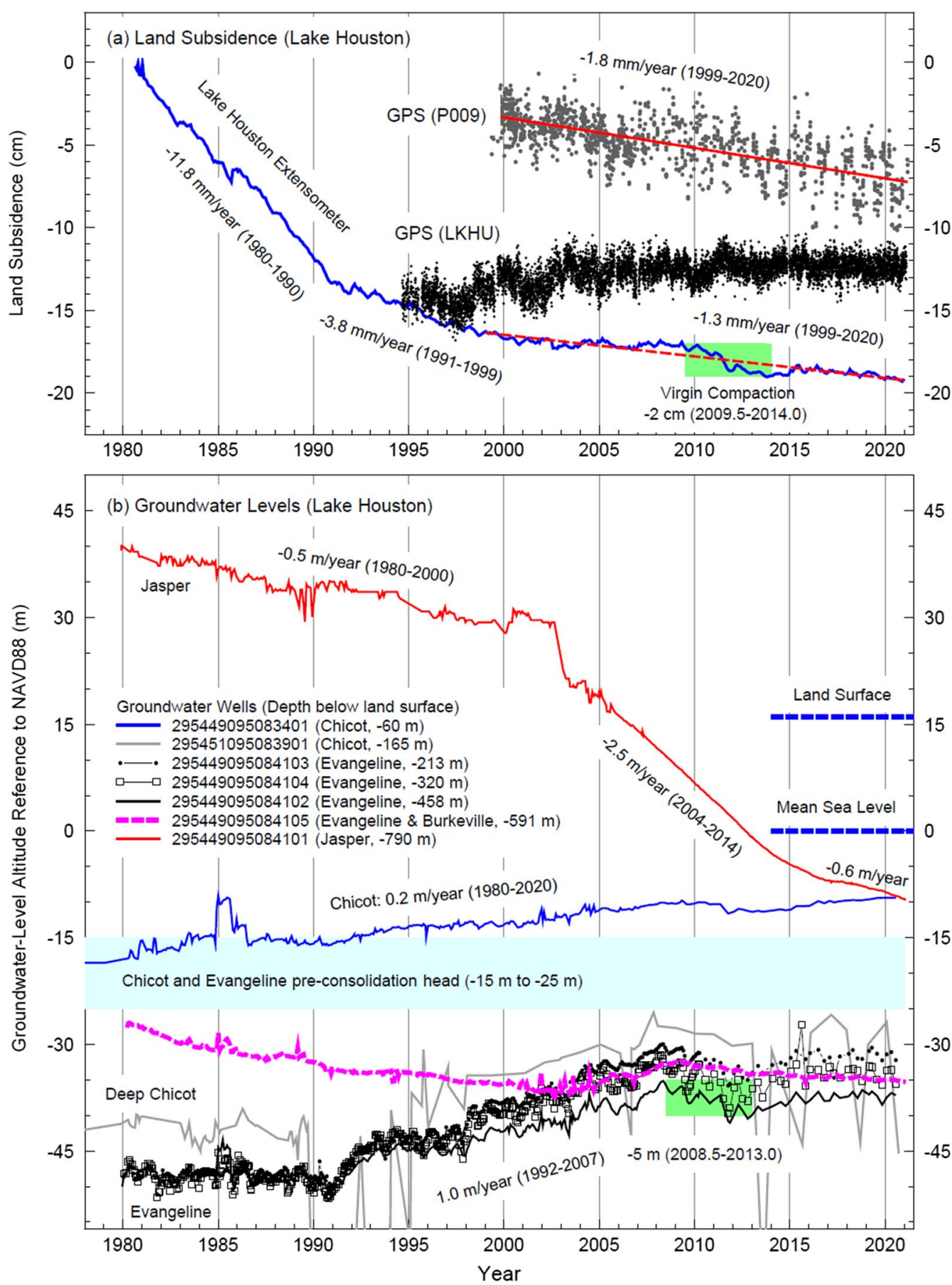

Fig. 11 Land subsidence and groundwater-level changes at the Lake Houston site. The green box indicates the virgin-compaction phase. The relative locations of wells, extensometer, and GPS are illustrated in Fig. 10. The location of GPS station P009 is marked in Fig. 1

\section{Pre-consolidation head}

The correlation between the primary aquifer compaction and groundwater-level changes can be explained by the Principle of Effective Stress (Terzaghi 1925):

$$
p^{\prime}=p-u_{w},
$$

where $p^{\prime}$ represents effective stress at the grain-to-grain contact points within the sediments; $p$ represents total 
stress due to the weight of the overlying water and sediments; $u_{w}$ represents pore-fluid stress, which is corresponding to the hydraulic head within local sediments. $u_{w}$ can be divided into two parts: a static or equilibrium head $\left(u_{s}\right)$ in the pore water and a transient pore-water stress $(u)$ in excess of the equilibrium pore-water stress. That is, $u_{w}=u_{s}+u$. Within aquitards, $u$ decays to zero slowly as water drains from an aquitard and stress equilibrium is approached. The total stress $(p)$ is also called geostatic stress, often regarded as unchanged during multi-decadal to century time scales. The total stress $(p)$ is balanced by the changes of pore-fluid pressure $\left(u_{w}\right)$ and effective stress $\left(p^{\prime}\right)$ exerted on clay particles. Pumping causes the reduction of pore-water stress $\left(u_{w}\right)$ in response to the declining of the hydraulic head. The reduced stress will be taken over by the solid grains. The maximum effective stress that a lay of sediments had sustained for a long period (century-scale) during its history is called pre-consolidation stress. When the effective stress exceeds the pre-consolidation stress, the clay grains will undergo significant, permanent rearrangement, resulting in inelastic (irreversible) compaction. The groundwater level corresponding to the pre-consolidation stress is called the pre-consolidation hydraulic head, simply the pre-consolidation head. In the Greater Houston region, the pre-consolidation head in each aquifer is approximate to the groundwater level before the 1940s when no excessive groundwater pumping occurred.

The Evangeline wells indicate that the groundwater hydraulic head remained constant during the 1980s, approximately at $-50 \mathrm{~m}$ (Fig. 11b). According to groundwater data in the long history illustrated in Fig. 7, regional-scale groundwater decline began in the 1970s. The Evangeline groundwater level started to rise in the early 1990s and reached approximately $-35 \mathrm{~m}$ at the end of 2008. Extensometer measurements indicate that the compaction of Evangeline was about $1 \mathrm{~mm}$ /year from 2000 to 2008. The minor subsidence rate suggests that the groundwater level was approaching the pre-consolidation head. A slight aquifer elastic expansion (or land surface rebound) is expected if the groundwater level had recovered to the pre-consolidation head (e.g., Galloway and Burbey 2011; Liu et al. 2019a; Zhou et al. 2021). Since no rebound was recorded around this period by the extensometer, it is most likely that the Evangeline groundwater level $(-35 \mathrm{~m})$ as of 2008 is still below the pre-consolidation head.

According to the investigations of USGS (e.g., Kasmarek and Robinson 2004; Kasmarek 2012) and UH (Kearns et al. 2015, 2019), the pre-consolidation heads of the Chicot and Evangeline aquifers are approximately -20 to $-30 \mathrm{~m}$ in southern Harris County. Since the land elevation in the Lake Houston area is about $10 \mathrm{~m}$ higher than the land elevation in southern Harris County, a slight hydraulic gradient would occur over the long distance from the north to the south. Combining the observations at this site and the pre-consolidation head in southern Harris County, we deduce that the Evangeline pre-consolidation head in Lake Houston area is approximately at -15 to $-25 \mathrm{~m}, 5 \mathrm{~m}$ higher than the pre-consolidation head in southern Harris County. Determination of the pre-consolidation head will be further discussed in the following sections. The long-term static groundwater hydraulic heads in the two aquifers are approaching the same level since the groundwater in the Chicot and the Evangeline aquifers are hydraulically connected. The pre-consolidation head in the Chicot aquifer would be the same as the pre-consolidation head in the Evangeline aquifer.

The groundwater level in the extensometer borehole (USGS ID: 295449095084105, completed at $591 \mathrm{~m}$ below land surface) was relatively stable during the past 4 decades, ranging from -25 to $-35 \mathrm{~m}$ (Fig. 11b). Since the borehole is terminated within the top of the Burkeville confining unit, the groundwater level represents the groundwater hydraulic head in the Burkeville confining unit. The thickness of the Burkeville confining unit is approximately $100 \mathrm{~m}$ in this area. The GPS antenna (LKHU) on the inner pole of the extensometer was stable over the past 2 decades, indicating no considerable compaction within the confining unit.

The groundwater level in the Jasper well (USGS ID: 295449095084101, $790 \mathrm{~m}$ below land surface) shows a gentle decline from 1980 to 2000 with an average decline rate of $0.5 \mathrm{~m} /$ year. A rapid groundwater-level drop of 10 m occurred within 2 years from 2002 to 2003, which did not induce any significant subsidence at the land surface. The Jasper groundwater continued to decline from 2004 to 2014 with an average rate of $-2.5 \mathrm{~m} /$ year. The decline rate slowed down since 2016 with an average rate of $-0.6 \mathrm{~m} /$ year (2016-2020). The Japer groundwater-level altitude declined to $-10 \mathrm{~m}$ at the beginning of 2020. Since there is no groundwater-withdrawal-induced compaction within the Jasper aquifer as verified by GPS data (LKHU), the Jasper pre-consolidation head in this area would be lower than the current groundwater level $(-10 \mathrm{~m})$.

\section{Virgin-compaction/head-decline ratio}

The aquifer compaction that occurred when the groundwater level is below the pre-consolidation head is also referred to as virgin compaction in the hydrology literature (e.g., Helm 1975; Galloway and Burbey 2011). The increased effective stress that exceeds the maximum historic stress (pre-consolidation stress) during the virgin compaction phase is called virgin stress. In this article, 
the virgin compaction is specifically referred to as the compaction that occurred when the groundwater level was continuously declining and below the pre-consolidation head, distinguishing it from the compaction that occurred when the groundwater level was stable or rising (see Fig. 11a).

The Evangeline wells completed at different depths indicate a rapid Evangeline groundwater-level drop of $5 \mathrm{~m}$ from mid-2008.5 to 2013 (Fig. 11b), which resulted in a compaction of $2 \mathrm{~cm}$ within the Evangeline aquifer during the period from mid-2009 to 2014 (Fig. 11a). Compaction occurs primarily due to the change in pore pressure in the clay beds in an aquifer. It takes time for the pressure change in the sand to propagate into the clay, for the compaction of clay to occur, and for the deep compaction to propagate to the land surface ultimately. The time lag between groundwater level drop and land subsidence occurring at this site is about 1 year. The $5-\mathrm{m}$ groundwater-level decline in the Evangeline aquifer led to a 2-cm virgin-compaction at this site. The ratio of virgin-compaction to head-decline is approximately 1:250. This ratio is a direct measure of the virgin compressibility of the Evangeline aquifer in this area. The compressibility is related to the geologic age, burial depth, and content (thickness) of clay layers within the aquifer. The Lake Houston site is only $17 \mathrm{~km}$ away from Montgomery County. According to USGS investigations (e.g., Kasmarek and Robinson 2004), the clay layers within the top aquifers (Chicot, Evangeline, upper Jasper) are similar on both sides of the boundary between Harris and Montgomery counties.

In practice, it is a challenge to estimate the virgin compressibility of an aquifer. On the one hand, it is often difficult to measure the compaction within a specific aquifer; on the other hand, it is difficult to get the groundwater and compaction measurements during the virgin-compaction phase. The groundwater levels have been rising while the land surface is continuously subsiding in the majority part of northern Harris and Montgomery counties since the mid-2010s. So, most GPS data are collected during the non-virgin-compaction phase. Fortunately, the datasets at Lake Houston provide valuable information to delineate the virgin-compaction/head-decline ratio in the Evangeline aquifer in this region.

In summary, the long-history of groundwater, extensometer, and GPS datasets at the Lake Houston site have contributed to essential conclusions: (1) groundwater pumping has not induced considerable compactions in the Burkeville confining unit and the Jasper aquifer in this area; (2) the pre-consolidation head in the Evangeline aquifers would be slightly higher than $-30 \mathrm{~m}$, and the pre-consolidation head in the Jasper aquifer would be deeper than $-10 \mathrm{~m}$; (3) the virgin-compaction/headdecline ratio in the Evangeline aquifer is approximately 1:250 in the Lake Houston area.

\section{Observations in The Woodlands}

The Woodlands is located in southern Montgomery County, $45 \mathrm{~km}$ north of Houston. The terrain is essentially flat, ranging from 40 to $60 \mathrm{~m}$ above sea level. The Woodlands is one of the fastest-growing suburban areas in Texas. Groundwater pumping has increased significantly since the 2000 s.

\section{Evangeline virgin-compaction/head-decline ratio}

Figure 12a shows the locations of six GPS stations and three sets of closely-spaced Evangeline and Jasper groundwater wells in The Woodlands area. Figure 12b, c
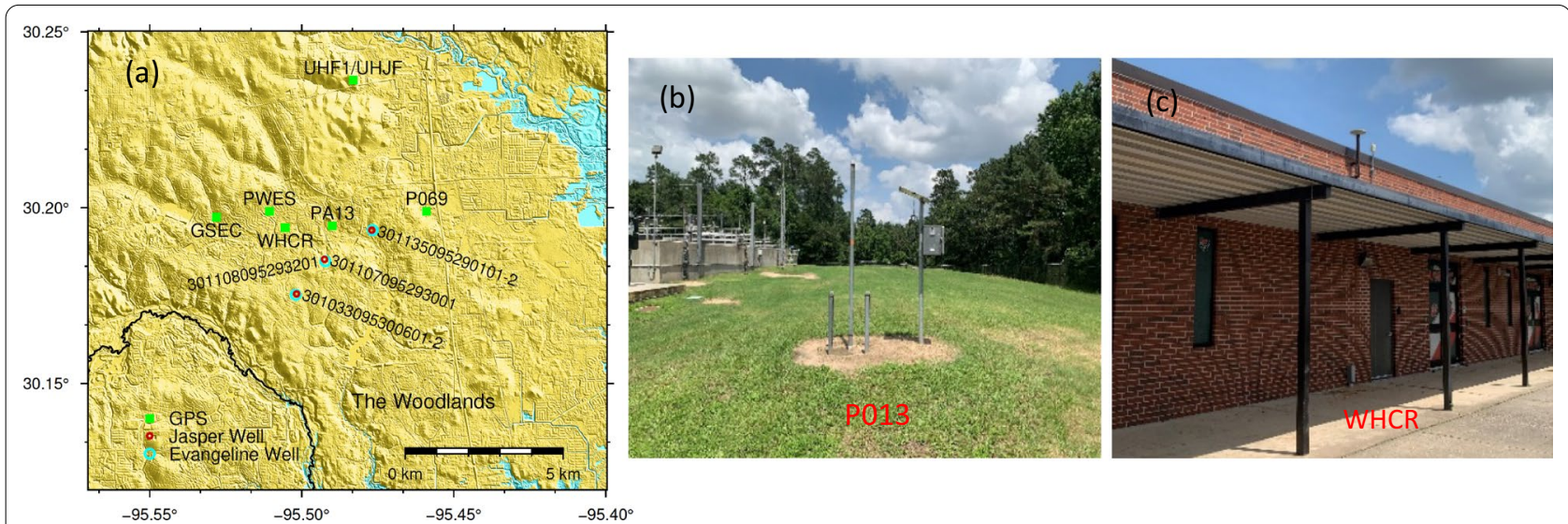

Fig. 12 a Map showing the locations of GPS and groundwater-level observation wells in The Woodlands area; $\mathbf{b}$ the permanent GPS antenna pole and solar power system at P013; c GPS antenna WHCR, which is located in The Woodlands High School. The LiDAR data for plotting the DEM map is available at NOAA (https://coast.noaa.gov/dataviewer) 
show site views at GPS stations P013 and WHCR. P013 is a typical PAM station installed on the free field. WHCR is a typical UH GPS station installed on school buildings. GSEC, PWES, and WHCR are installed on single-story school buildings in Galatas Elementary School, Powell Elementary School, and The Woodlands High School. Figure 13a depicts the GPS-derived land subsidence time series at these GPS sites. GPS-derived subsidence time series at these six sites consistently suggest that the average rate of ongoing subsidence (2016-2020) in this area is approximately $7-8 \mathrm{~mm} /$ year. P013 has a history of 2 decades (2000-2020) and shows the occurrence of an acceleration of subsidence in the middle of 2004. The subsidence rate changed from $11 \mathrm{~mm} /$ year (2001-2004.5) to $16 \mathrm{~mm}$ /year (2005-2015). There has been a deceleration of subsidence since 2016. The Woodlands area began receiving surface water from Lake Conroe in 2015. Subsequently, land subsidence reduced from $16 \mathrm{~mm} /$ year (2005-2015) to $8 \mathrm{~mm} /$ year (2016-2020).

Figure 13b depicts the history of groundwater-level changes in The Woodland area. Measurements at three Evangeline wells indicate that the Evangeline groundwater-level altitude was below the pre-consolidation head and declined with a steady rate of $2.4 \mathrm{~m}$ /year from 2001 to 2014. The groundwater level began to rise after the surface water was available for municipal use since approximately 2015 . The observations at the Lake Houston site have suggested that the Evangeline virgin-compaction/head-decline ratio in this area is about 1:250 (Fig. 11). The groundwater-level decline of $2.4 \mathrm{~m} /$ year in the Evangeline aquifer would result in a compaction approximately $10 \mathrm{~mm} /$ year. GPS measurements at P013 indicate that the total compaction rate was $16 \mathrm{~mm} /$ year from 2004 to 2015. The compactions of the Chicot aquifer and the Burkeville confining unit are ignorable, as previously discussed. That means the compaction of the Jasper aquifer resulted in the remaining $6 \mathrm{~mm}$ /year. The measurements at three Jasper wells closely-spaced with these three Evangeline wells indicate that the Jasper groundwater-level decline rate was approximately $4.8 \mathrm{~m} /$ year from 2004 to 2014. Accordingly, the virgin-compaction/head-decline ratio in the Jasper aquifer in this area is approximately 1:800. That is, the Jasper Aquifer is three to four times less susceptible to compaction than the overlying Evangeline aquifer in this area.

The groundwater level and GPS datasets also suggest that the Jasper aquifer contributed approximately onethird of the total compaction (6 of $16 \mathrm{~mm} /$ year) from 2005 to 2015. Unfortunately, it is difficult to distinguish the contribution of the Jasper aquifer from the land subsidence (total compaction) since 2016. Groundwater levels in both the Jasper and Evangeline aquifers have been rising since 2016. The ongoing compactions since 2016 are in a none-virgin-compaction phase. The compressibility of each aquifer during the non-virgin-compaction phase could be differ from the compressibility during the virgin-compaction phase.

\section{Jasper pre-consolidation head}

GPS-derived subsidence at P013 shows a reduction of the subsidence rate in the middle of 2004. The subsidence rate was $11 \mathrm{~mm} /$ year from 2001 to 2003, which is comparable to the rate that could be produced by the compaction of the Evangeline aquifer alone $(\sim 10 \mathrm{~mm} /$ year) with the groundwater hydraulic head decline rate of $2.4 \mathrm{~m} /$ year. There were no substantial groundwater-level changes in the Evangeline aquifer around 2004. So, the increased subsidence rate (from 11 to $16 \mathrm{~mm}$ /year) might be primarily contributed by the additional compaction of the Jasper aquifer. In other words, the compaction of the Jasper aquifer likely began in 2004. The Jasper groundwater level in 2004 would be close to the pre-consolidation head of the Jasper aquifer. Figure 13b indicates that the Jasper groundwater-level altitude in 2004 was approximately $-25 \mathrm{~m}$. The observations at the Lake Houston site already concluded that the pre-consolidation head in the Jasper aquifer must be below $-10 \mathrm{~m}$. It is very likely that the pre-consolidation head in the Jasper aquifer is between -15 and $-25 \mathrm{~m}$, which is similar to the pre-consolidation heads in the Chicot and Evangeline aquifers in this area. The land elevation at P013 is approximately $50 \mathrm{~m}$ above sea level. The Jasper pre-consolidation head in this area would be $65-75 \mathrm{~m}$ below the land surface.

In summary, the observations at The Woodlands suggest: (1) the compaction in the Jasper aquifer began in the mid-2000s in The Woodlands area and contributed to approximately one-third of the land subsidence from the mid-2000s to mid-2010s; (2) the pre-consolidation head of the Jasper aquifer is approximately at -15 to $-25 \mathrm{~m}$; (3) the virgin-compaction/head-decline ratio in the Jasper aquifer is approximately 1:800 in Montgomery County.

\section{Observations in the City of Conroe}

The City of Conroe is the county seat, the economic and geographic center of Montgomery County (Fig. 5). Figure 14a depicts four permanent GPS stations, three Chicot wells, one Evangeline well, and six Jasper wells in the Conroe area. Figure 14b shows a site photo at the GPS antenna TXCN, mounted on the roof of the office building of TxDOT at Conroe. Figure 15 illustrates GPSderived subsidence and groundwater level changes during the past 2 decades. TXCN (2004-2020) recorded steady subsidence from 2007 to 2015 with an average rate of $-14 \mathrm{~mm} /$ year. The subsidence rate has been reduced 

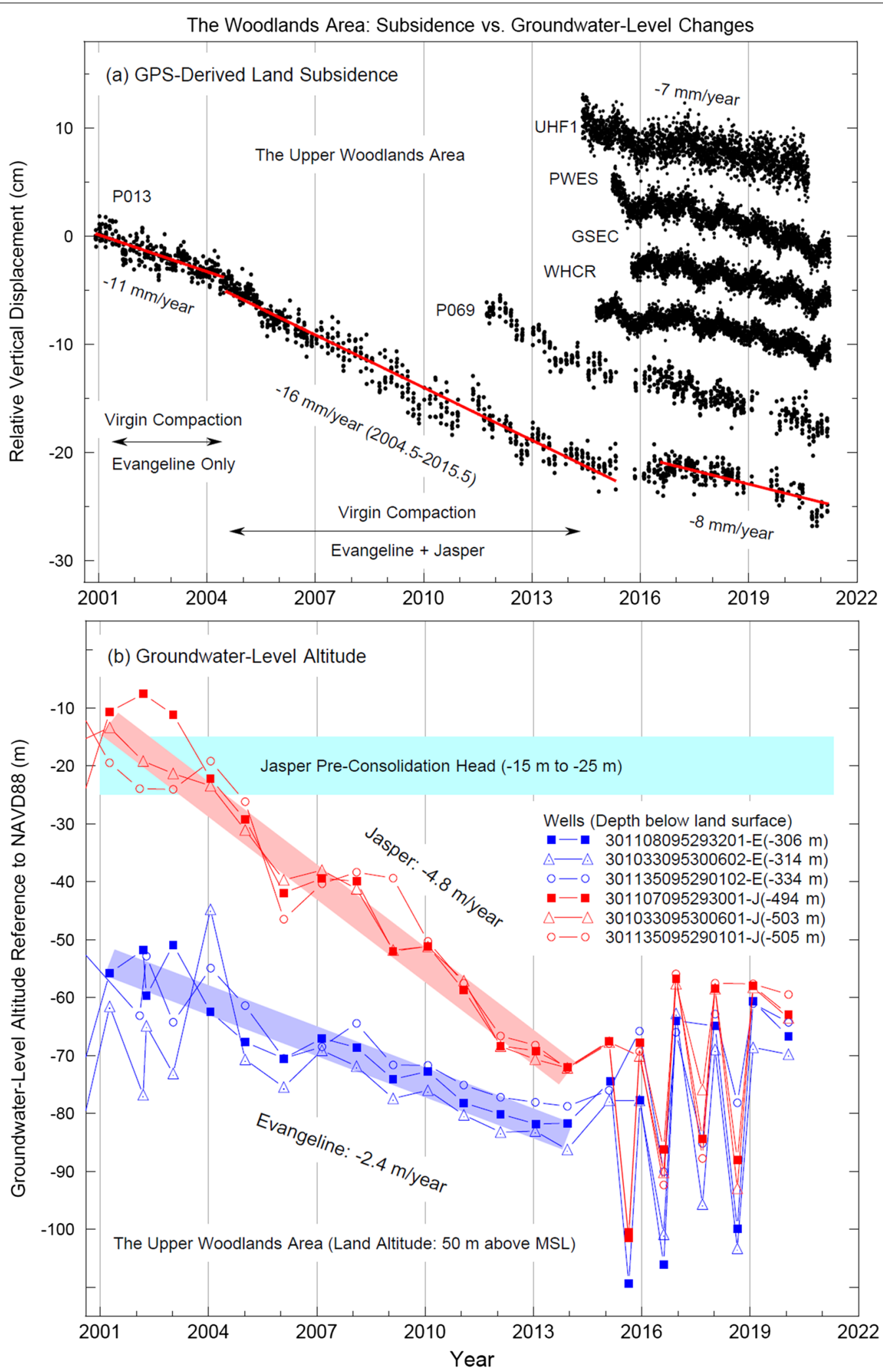

Fig. 13 GPS-derived subsidence and groundwater levels in The Woodland area. The locations of these wells and GPS are marked in Fig. 12 

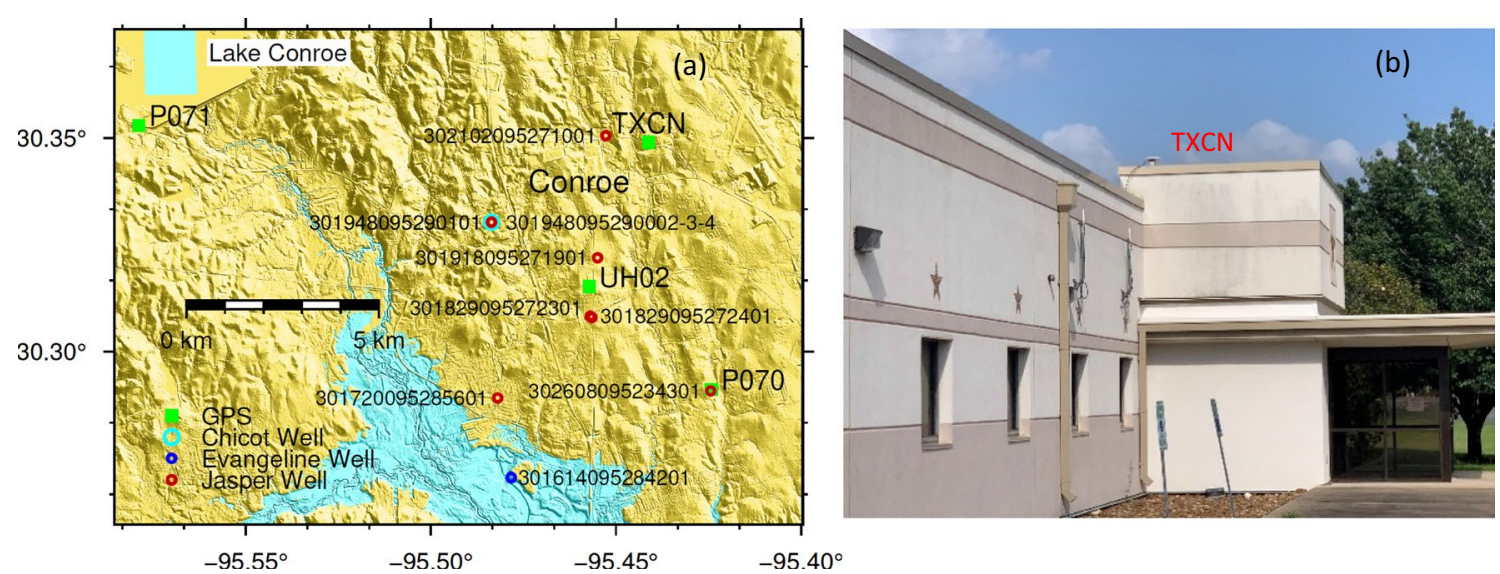

Fig. 14 a Map showing the locations of GPS stations and groundwater-level observation wells in the Conroe area; b GPS antenna TXCN, mounted on the roof of the Texas Department of Transportation office building in the City of Conroe, Montgomery County. The LiDAR data for plotting the DEM map is available at NOAA (https://coast.noaa.gov/dataviewer)

to $6 \mathrm{~mm} /$ year since 2016. Observations at other three GPS stations (UH02, P070, P071) also suggest that the ongoing subsidence rate is approximately $6 \mathrm{~mm} /$ year in this area (Fig. 15a). There is only one Evangeline well (USGS ID: 301614095284201, terminated $216 \mathrm{~m}$ below land surface) in the Conroe area, which indicates a groundwater level decline rate of $2.7 \mathrm{~m}$ /year (2004-2013) (Fig. 15b). The Jasper groundwater level declined with a rate of $3.2 \mathrm{~m} /$ year during the same period. The $2.7 \mathrm{~m} /$ year groundwater-level decline in the Evangeline aquifer would lead to subsidence of approximately $11 \mathrm{~mm} /$ year based on the virgin-compress/head-decline ratio of 1:250; the $3.2 \mathrm{~m} /$ year groundwater-level drop in the Jasper aquifer will lead to subsidence of approximately $4 \mathrm{~mm}$ /year based on the virgin-compress/head-decline ratio of 1:800. The total subsidence rate would be about $15 \mathrm{~mm} /$ year. GPS station TXCN did record land surface subsidence of $14 \mathrm{~mm} /$ year during this period (2007-2015). The analytical solution $(15 \mathrm{~mm} /$ year $)$ and the direct measurement (14 $\mathrm{mm} /$ year) agree with each other, which further verifies that the estimated virgin-compaction/head-decline ratios are reasonable.

The groundwater level in the Jasper aquifer declined to below $-25 \mathrm{~m}$ in the early 2006. GPS-derived subsidence time series at TXCN indicated a rapid drop of the land surface at the end of 2006 (Fig. 15a). The additional compaction of the Jasper aquifer possibly caused the increased subsidence rate. So, $-25 \mathrm{~m}$ is a reasonable estimate of the lower bound of the pre-consolidation head in the Jasper aquifer. According to the declining trend of the Evangeline groundwater, the Evangeline groundwater level in the Conroe area was above the pre-consolidation before 2000. In other words, land subsidence in the Conroe area would be minor before 2000 since the groundwater levels in all aquifers (Chicot, Evangeline, Jasper) were above their pre-consolidation heads $(-15$ to $-25 \mathrm{~m})$.

In summary, the compaction of the Evangeline aquifer began in the early 2000s in the Conroe area, and the compaction of the Jasper aquifer began in the mid-2000s. The Jasper compaction contributed approximately onethird of the total compaction (subsidence) from 2007 to 2015. The observations in the Conroe area confirmed that the estimates of pre-consolidation heads and virgincompaction/head-decline ratios in the Evangeline and Jasper aquifers are reasonable.

\section{Observations in the Southeast area}

Figure 16 depicts land subsidence and groundwater-level changes in southeastern Montgomery County and adjacent areas. Locations of groundwater-level observation wells and GPS are marked in Fig. 5. GPS station P072 is in the New Caney area. P012 is next to the southeast border of Montgomery County, adjacent to Kingwood, the largest master-planned residential community in northern Harris County and southern Montgomery County. COH6 and P065 are two GPS stations in Harris County, approximately $5 \mathrm{~km}$ from Montgomery County. GPS-derived subsidence at these four sites indicates that the ongoing subsidence since the 2010s in southeastern Montgomery County is about $5-8 \mathrm{~mm} /$ year (Fig. 16a). The Evangeline groundwater level was stable and close to the pre-consolidation head during past 3 decades (Fig. 16b).

The Jasper well at the eastern border (USGS ID: 301911095092901), near Cleveland, indicates that the Jasper groundwater level has been declining over its entire history since the 1990s and is still above the 

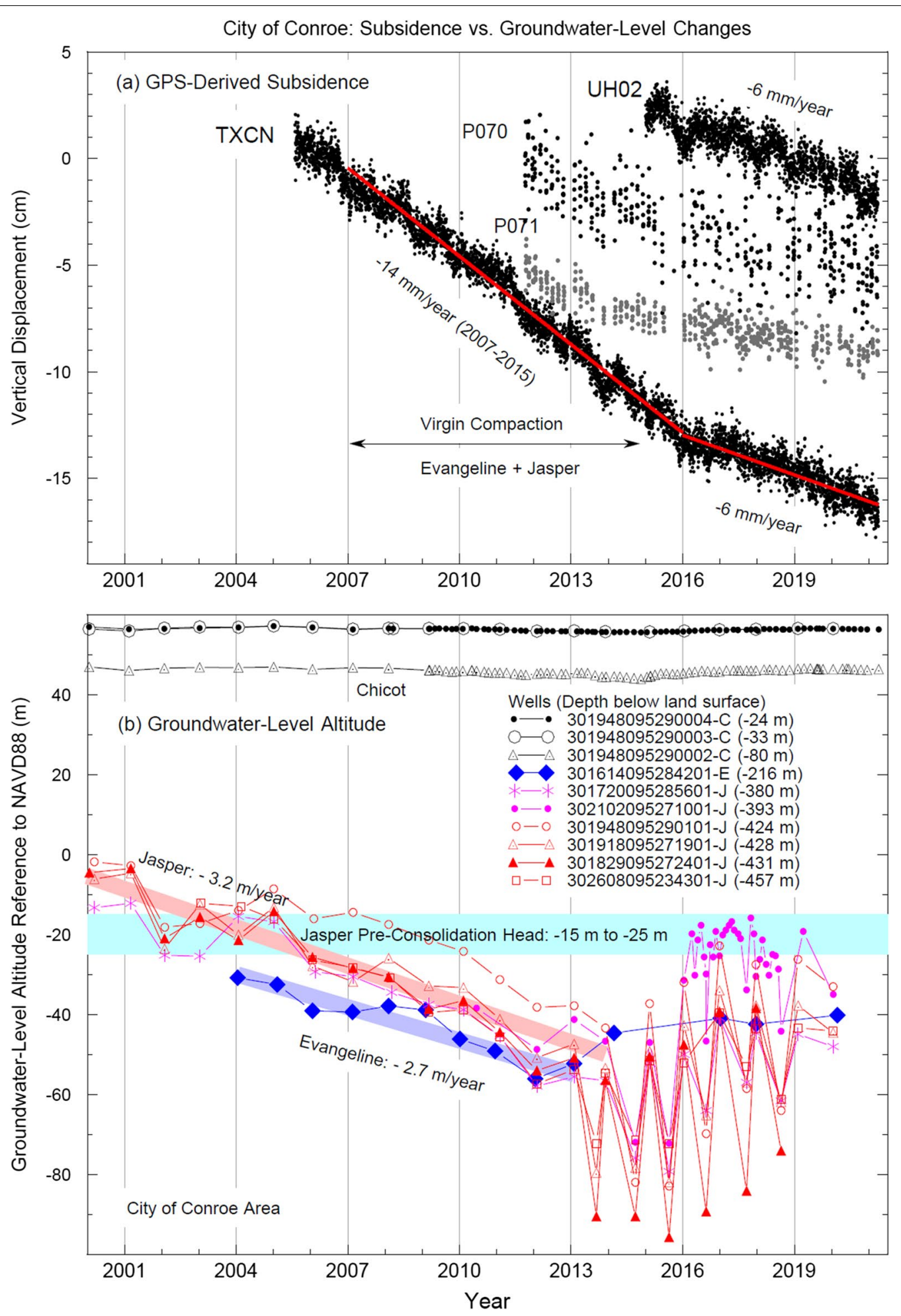

Fig. 15 GPS-derived land subsidence and groundwater-level changes in Conroe area. The locations of these wells and GPS are marked in Fig. 14 

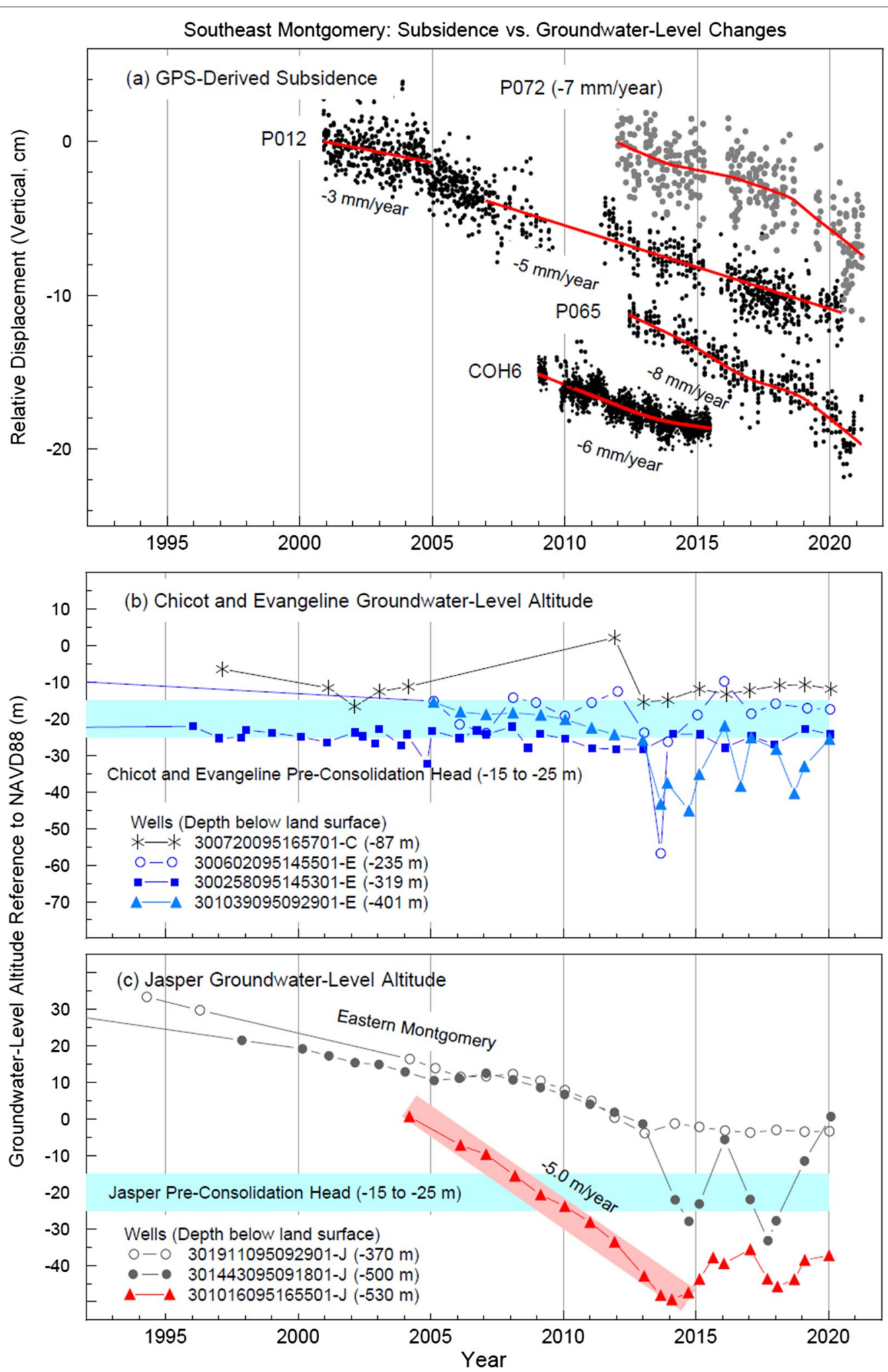

Fig. 16 GPS-derived land subsidence and groundwater levels in southeastern Montgomery County. The locations of GPS stations and groundwater wells are marked in Fig. 5 
pre-consolidation head as of 2020 (Fig. 16c). The Jasper well near Splendora (USGS ID: 301443095091801) indicates that the Jasper groundwater has been approaching the pre-consolidation head since the mid-2010s. The Jasper well (USGS ID: 301016095165501$)$ close to P012 shows that the Jasper groundwater level declined to the pre-consolidation head in 2006 and reached the lowest level in 2014. The Jasper groundwater level began to rise in 2015 following the reduction of groundwater pumping. The average decline rate of the Jasper groundwater level was approximately $5.0 \mathrm{~m} /$ year (2004-2014), which would produce approximately $6 \mathrm{~mm}$ /year compaction according to the virgin-compaction/head-decline ratio of 1:800. The analytical compaction rate of $6 \mathrm{~mm}$ /year within the Jasper aquifer is comparable with the total compaction rates (5-8 $\mathrm{mm} /$ year) recorded by GPS in this area. That is, the ongoing land subsidence in this area is dominated by the compaction of the Jasper aquifer. This result is consistent with the fact that the Chicot and Evangeline groundwater levels were above their pre-consolidation head during the past 2 decades (Fig. 16b).

In summary, the observations in southeastern Montgomery County indicate that land subsidence in this area is dominated by the compaction of the Jasper aquifer since the late 2000s. The observations further confirm that the estimates of regional pre-consolidation heads and the virgin-compaction/head-decline ratios are reasonable.

\section{Observations in the Southwest area}

Figure 17 illustrates GPS-derived subsidence and groundwater-level changes in southwestern Montgomery County. Locations of these GPS stations and groundwater wells are marked in Fig. 5. GPS stations P017 and ROD1 are located in northern Harris County, approximately $5 \mathrm{~km}$ to Montgomery County. GPS measurements at P017 indicate that the subsidence rate was up to $2 \mathrm{~cm} /$ year during the 2000s and slowed down since the mid-2010s. The ongoing subsidence in this area is about 7-12 mm/year (2015-2020) (Fig. 17a). The Chicot groundwater level was stable and above the pre-consolidation during the past 3 decades. The Evangeline groundwater level declined to below the pre-consolidation head in the late 1990s and retained stable during the 2010s (Fig. 17b). The Jasper groundwater level declined to the pre-consolidation head in the mid-2000s and retained stable during the 2010s (Fig. 17c). The Jasper groundwater level declined with a rate of $5 \mathrm{~m}$ /year during the virgin-compaction phase (2005-2010). According to the virgin-compaction/ head-decline ratio of $1: 800$, the $5 \mathrm{~m} /$ year head-decline would result in approximately $6 \mathrm{~mm} /$ year of compaction. The contribution of the Jasper compaction was also approximately one-third of the land subsidence (6 $\mathrm{mm}$ /year vs. $15-20 \mathrm{~mm}$ /year) during the virgin compaction phase. Both the Evangeline and Jasper groundwater-level altitudes are approximately $30 \mathrm{~m}$ below their pre-consolidation heads as of 2020. Land subsidence will continue until groundwater levels in both the Evangeline and Jasper aquifers recover to their pre-consolidation heads.

\section{Discussion}

Land subsidence is probably one of the most evident environmental effects of excessive groundwater pumping. The GPS-derived positional time series presented in this study suggest that the rate of subsidence varies considerably over time and space, depending on groundwater levels and the changes of groundwater levels in both the Evangeline and Jasper aquifers. A remarkable reduction of the subsidence rate has been recorded by GPS in central and southern Montgomery County since the mid-2010s due to the reduction of pumping as a result of groundwater regulation. The observations presented in this study reveal that land subsidence is a human-induced "natural" hazard depending on how groundwater is managed and regulated.

LSGCD adjusted its groundwater regulation rules in 2020. The 2020 regulatory plan no longer requires the large volume groundwater users to follow the previous rule of reducing their groundwater production by thirty percent (30\%) of their Total Qualifying Demand (LSGCD 2020). It is likely that the groundwater levels in Montgomery County, as well as in its neighboring counties, will further decline in the future. As of 2020, the Jasper groundwater-level altitude is approximately $20-40 \mathrm{~m}$ below the pre-consolidation head in central and southern Montgomery County; the Evangeline groundwater-level altitude is about $40-60 \mathrm{~m}$ below the pre-consolidation head in southern Montgomery County. Subsidence will continue to occur as long as the groundwater hydraulic head in either the Evangeline or the Jasper aquifer remains below its pre-consolidation head.

GPS and groundwater monitoring datasets in Montgomery County provide first-hand information for tracking land subsidence and understanding the causeand-effect relationship in groundwater-level changes and aquifer compactions. By 2020, subsidence over $5 \mathrm{~mm} /$ year is ongoing in central and southern Montgomery County, approximately half the area of the entire county. Continuously conducting county-wide groundwaterlevel and land subsidence monitoring is essential for understanding the temporospatial progress of subsidence and for future groundwater supply planning and management. 


\section{Southwest Montgomery: Subsidence vs. Groundwater-Level Change}
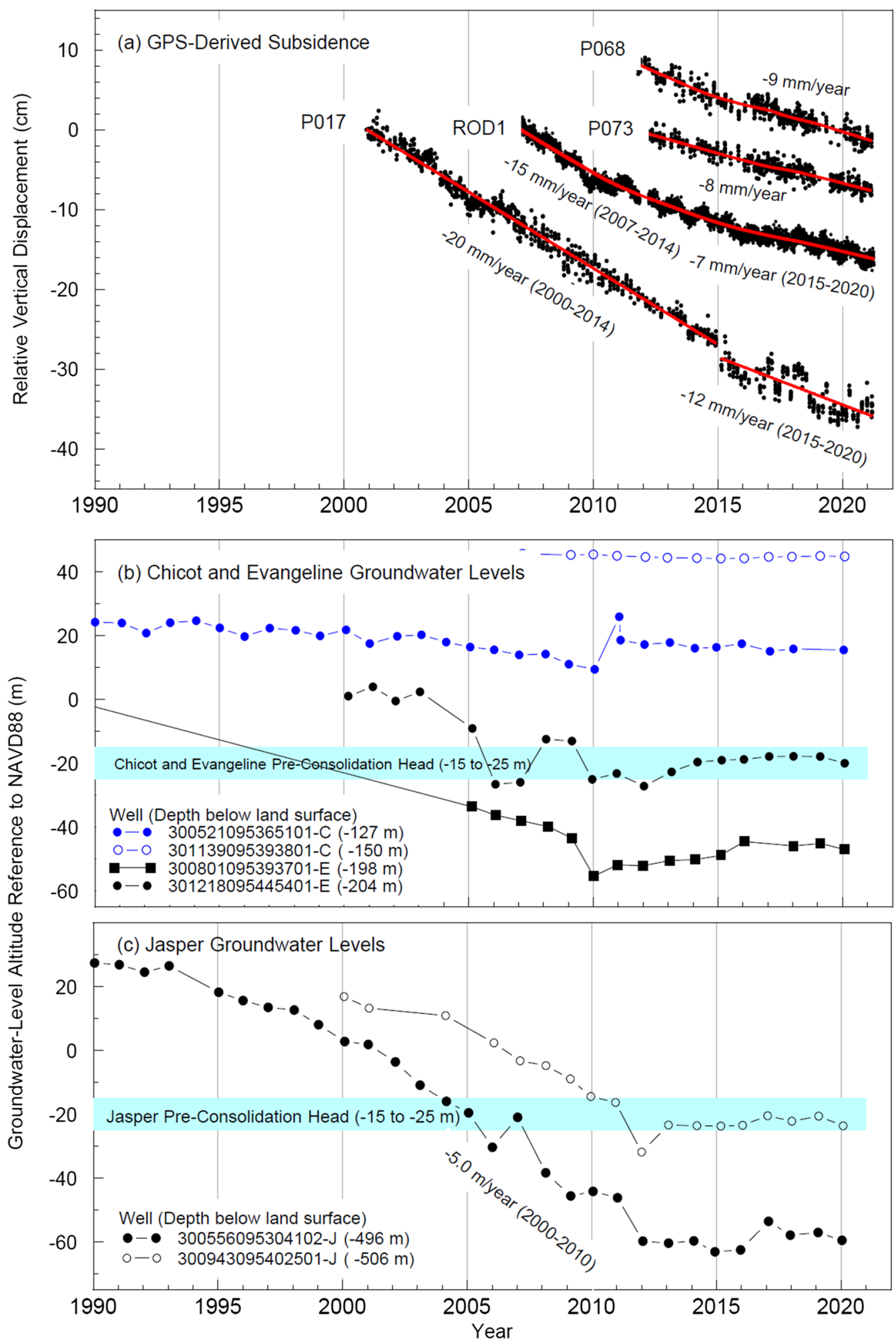

Fig. 17 GPS-derived land subsidence and groundwater levels in southwestern Montgomery County. The locations of GPS stations and groundwater wells are marked in Fig. 5 


\section{Conclusions}

Based on the long-term groundwater level and land subsidence observations in the Montgomery County and northern Harris County, we conclude that:

(1) the pre-consolidation heads of the three aquifers in the Montgomery County area are close to each other, approximately 15-25 m below sea level;

(2) the compactions from the Chicot aquifer and the Burkeville confining unit during the past 3 decades would be minor even if they did occur;

(3) the ongoing subsidence in Montgomery County since the mid-2000s has been dominated by the compactions of the Evangeline and Jasper aquifers;

(4) the compaction of the Jasper aquifer began in the mid-2000s in The Woodlands and Conroe areas and contributed about one-third of the land subsidence since the mid-2000s;

(5) the virgin-compaction/head-decline ratio is approximately 1:250 in the Evangeline aquifer and 1:800 in the Jasper aquifer in central and southern Montgomery County.

\begin{abstract}
Acknowledgements
The authors acknowledge LSGCD, HGSD, USGS, TxDOT, SmartNet, and UNAVCO for archiving and sharing groundwater and GPS data with the public The authors acknowledge the comments and suggestions from Mr. Michael R. Keester (LRE water) and two anonymous reviewers. Figs. 1, 4, 5, 8, 12a, and 14a are generated using the Generic Mapping Tools (GMT), developed by Wessel et al. (2013).
\end{abstract}

\section{Authors' contributions}

K.W. and G.W. processed data and prepared the draft. B.C., H.L., and Y.B. analyzed data, reviewed, and edited the manuscript. All authors read and approved the final manuscript.

\section{Funding}

Hanlin Lius's contribution to this work was supported by the National Key R\&D Program of China (No. 2019YFB2102700); Yan Bao's contribution to this work was supported by National Science Foundation of China (No. 51829801).

\section{Availability of data and materials}

GPS raw data used for this study are available at HGSD (https://hgsubsiden ce.org), UNAVCO (https://www.unavco.org), and NGS (https://www.ngs.noaa. gov/CORS). The groundwater measurements are available at USGS (https:// waterdata.usgs.gov/nwis). All processed data, models, or code that support the findings of this study are available from the corresponding author (gwang@uh.edu) upon request.

\section{Declaration}

\section{Competing interests}

The authors declare no conflict of interest.

\section{Author details}

${ }^{1}$ Department of Earth and Atmospheric Sciences, University of Houston, Houston 77204, USA. ${ }^{2}$ Institute of Urban Smart Transportation and Safety Maintenance, Shenzhen University, Shenzhen 518060, China. ${ }^{3}$ Key Laboratory of Urban Security and Disaster Engineering of Ministry of Education, Beijing University of Technology, Beijing 100029, China.
Received: 17 June 2021 Accepted: 20 October 2021

Published online: 31 October 2021

\section{References}

Agudelo G, Wang G, Liu Y, Bao Y, Turco MJ (2020) GPS geodetic infrastructure for subsidence and fault monitoring in Houston, Texas, USA. Proc Int Assoc Hydrol 382:11-18

Baker ET, Jr (1979) Stratigraphic and hydrogeologic framework of part of the coastal plain of Texas. Texas Department of Water Resources Report 236, p 43

Braun CL, Ramage JK (2020) Status of groundwater-level altitudes and longterm groundwater-level changes in the Chicot, Evangeline, and Jasper aquifers, Houston-Galveston region, Texas, 2020. U.S. Geological Survey Scientific Investigations Report 2020-5089, p 18

Campbell MD, Campbell MD, Wise HM (2018) Growth faulting and subsidence in the Houston, Texas area: guide to the origins, relationships, hazards, potential impacts and methods of investigation: an update. J Geol Geosci 2:1-53

Casarez IR (2020) Aquifer extents in the coastal lowlands aquifer system regional groundwater availability study area in Texas, Louisiana, Mississippi, Alabama, and Florida. U.S. Geological Survey data release. https:// doi.org/10.5066/P9BH2KG2

Chowdhury AH, Turco MJ (2006) Geology of the Gulf coast aquifer, Texas. Texas Water Dev Board Rep 365:23-50

Coplin LS, Galloway D (1999) Houston-Galveston, Texas. Land subsidence in the United States. US Geol Surv Circ 1182:35-48

Furnans J, Keester M, Colvin D, Bauer J, Barber J, Gin G, Danielson V, Erickson L, Ryan R, Khorzad K, Worsley A, Snyder G (2018) Final report: identification of the vulnerability of the major and minor aquifers of Texas to subsidence with regard to groundwater pumping. Texas Water Development Board, Contract report No. 1648302062, p 434

Gabrysch RK (1967) Development of ground water in the Houston district, Texas, 1961-65. Texas Water Dev Board Rep 63:35

Galloway DL, Burbey TJ (2011) Review: regional land subsidence accompanying groundwater extraction. Hydrogeol J 19:1459-1486

Greuter A, Petersen P (2021) Determination of groundwater withdrawal and subsidence in Harris and Galveston counties-2020. Harris-Galveston Subsidence District Report. https://hgsubsidence.org/wp-content/uploa ds/2021/05/2020-HGSD-AGR_Full-Report-1.pdf

Helm DC (1975) One-dimensional simulation of aquifer system compaction near Pixley, Calif.: 1. constant parameters. Water Resour Res 11(3):465-478

Kasmarek MC (2012) Hydrogeology and simulation of groundwater flow and land-surface subsidence in the northern part of the Gulf Coast aquifer system, Texas, 1891-2009 (ver. 1.1, December 2013). U.S. Geological Survey Scientific Investigations Report 2012-5154, p 55

Kasmarek MC, Robinson JL (2004) Hydrogeology and simulation of groundwater flow and land-surface subsidence in the northern part of the Gulf Coast aquifer system, Texas. U.S. Geological Survey Scientific Investigations Report 2004-5102, p 111

Kasmarek MC, Ramage JK, Johnson MR (2016) Water-level altitudes 2016 and water-level changes in the Chicot, Evangeline, and Jasper aquifers and compaction 1973-2015 in the Chicot and Evangeline aquifers, HoustonGalveston region, Texas. U.S. Geological Survey Scientific Investigations Map 3365, pamphlet, 16 sheets, scale 1:100,000

Kearns TJ, Wang G, Bao Y, Jiang J, Lee D (2015) Current land subsidence and groundwater level changes in the Houston metropolitan area (2005-2012). J Surv Eng 141(4):05015002

Kearns TJ, Wang G, Turco MJ, Welch J, Tsibanos V, Liu H (2019) Houston16: a stable geodetic reference frame for subsidence and faulting study in the Houston metropolitan area, Texas. US Geod Geodyn 10(5):382-393

Kelley V, Deeds N, Young SC, Pinkard J, Sheng Z, Seifert J, Marr S (2018) Subsidence risk assessment and regulatory considerations for the brackish Jasper aquifer-Harris-Galveston and Fort Bend Subsidence Districts. Report prepared for Harris-Galveston Subsidence District and Fort Bend Subsidence District, p 69

Khan SD, Stewart RR, Otoum M, Chang L (2013) A geophysical investigation of the active Hockley fault system near Houston, Texas. Geophysics 78:B177-B185 
Liu Y, Li J, Fang Z (2019a) Groundwater level change management on control of land subsidence supported by borehole extensometer compaction measurements in the Houston-Galveston region. Texas Geosci 9(5):223

Liu Y, Sun X, Wang G, Turco MJ, Agudelo G, Bao Y, Zhao R, Shen S (2019b) Current activity of the Long Point fault in Houston, Texas constrained by continuous GPS measurements (2013-2018). Remote Sens 11(10):1213

LSGCD (2013) Lone Star Groundwater Conservation District Management Plan-re-adopted November 12, 2013. https://www.lonestargcd.org/ district-rules-1

LSGCD (2020) 2020 Lone Star Groundwater Conservation District Management Plan, as approved on May 15, 2020. https://www.lonestargcd.org/ district-rules-1

Miller MM, Shirzaei M (2019) Land subsidence in Houston correlated with flooding from Hurricane Harvey. Remote Sens Environ 225:368-378

Petersen C, Turco MJ, Vinson A, Turco JA, Petrov A, Evans M (2020) Groundwater regulation and the development of alternative source waters to prevent Subsidence, Houston region, Texas, USA. Proc IAHS 382:797-801

Popkin BP (1971) Groundwater resources of Montgomery County, Texas. Texas Water Dev Board Rep 136:143

Qu F, Lu Z, Zhang Q, Bawden GW, Kim J, Zhao C, Qu W (2015) Mapping ground deformation over Houston-Galveston, Texas using multi-temporal InSAR. Remote Sens Environ 169:290-306

Qu F, Lu Z, Kim JW, Zheng W (2019) Identify and monitor growth faulting using InSAR over northern greater Houston, Texas, USA. Remote Sens 11(12):1498

Ramage JK (2020) Depth to groundwater measured from wells completed in the Chicot, Evangeline, and Jasper aquifers, Houston-Galveston region, Texas, 2020. U.S. Geological Survey data release

Ramage JK, Shah SD (2019) Cumulative compaction of subsurface sediments in the Chicot and Evangeline aquifers in the Houston-Galveston region, Texas (ver. 2.0, June 2020). U.S. Geological Survey data release

Shah SD, Ramage JK, Braun CL (2018) Status of groundwater-level altitudes and long-term groundwater-level changes in the Chicot, Evangeline, and Jasper aquifers, Houston-Galveston region, Texas, 2018. U.S. Geological Survey Scientific Investigations Report 2018-5101, p 18

Terzaghi K (1925) Principles of soil mechanics: I-Phenomena of cohesion of clays. Eng News-Rec 95(19):742-746

Thornhill MR, Keester MR (2020) Subsidence investigations-phase 1: assessment of past and current investigations, prepared for Lone Star Groundwater Conservation District. https://www.lonestargcd.org/subsidence

Turco MJ, Petrov A (2015) Effects of groundwater regulation on aquifer-system compaction and subsidence in the Houston-Galveston Region, Texas, USA. Proc Int Assoc Hydrol Sci 372:511-514

Wang G (2021) The 95\% confidence interval for the GNSS-derived site velocities. J Surv Eng. https://doi.org/10.1061/(ASCE)SU.1943-5428.0000390
Wang G, Soler T (2014) Measuring land subsidence using GPS: ellipsoid height vs. orthometric height. J Surv Eng 141:05014004

Wang G, Yu J, Ortega J, Saenz G, Burrough T, Neill R (2013) A stable reference frame for the study of ground deformation in the Houston metropolitan area, Texas. J Geod Sci 3:188-202

Wang G, Yu J, Kearns TJ, Ortega J (2014) Assessing the accuracy of long-term subsidence derived from borehole extensometer data using GPS observations: case study in Houston, Texas. J Surv Eng 140(3):05014001

Wang G, Welch J, Kearns T, Yang L, Serna J Jr (2015) Introduction to GPS geodetic infrastructure for land subsidence monitoring in Houston, Texas, USA. Proc Int Assoc Hydrol Sci 372:297-303

Wang G, Turco M, Soler T, Kearns TJ, Welch J (2017) Comparisons of OPUS and PPP solutions for subsidence monitoring in the greater Houston area. J Surv Eng 143(4):05017005

Wang G, Zhou X, Wang K, Ke X, Zhang Y, Zhao R, Bao Y (2020) GOM20: a stable geodetic reference frame for subsidence, faulting, and sea-level rise studies along the Coast of the Gulf of Mexico. Remote Sens 12(3):350

Welch J (2018) Current ground motions in Montgomery, West Liberty, and Northern Harris counties derived from continuous GPS motions. Mather Thesis, Department of Earth and Atmospheric Sciences, University of Houston

Wessel P, Smith WHF, Scharroo R, Luis J, Wobbe F (2013) Generic mapping tools: improved version released. EOS Trans Am Geophys Union 94(45):409-410

Young SC, Ewing T, Hamlin S, Baker E, Lupton D (2012) Final report-updating the hydrogeologic framework for the northern portion of the gulf coast aquifer. Contract report for the Texas Water Development Board, p 285

Young SC, Jigmond M, Deeds N, Blainey J, Ewing TE, Banerj D, Piemonti D, Jones T, Griffith C, Lupton D, Martinez G, Hudson C, Hamlin S, Sutherland $J(2016)$ Final report: identification of potential brackish groundwater production areas-Gulf Coast Aquifer System. Contract report to the Texas Water Development Board, p 636

Yu J, Wang G, Kearns TJ, Yang L (2014) Is there deep-seated subsidence in the Houston-Galveston area. J Geophys 942834:1-11

Zhou F (2020) The correlation between current land subsidence and groundwater levels in Montgomery County, Texas. Mather Thesis, Department of Earth and Atmospheric Sciences, University of Houston

Zhou X, Wang G, Wang K, Liu H, Lyu H, Turco MJ (2021) Rates of natural subsidence and submergence along the Texas coast derived from GPS and tide gauge measurements (1904-2020). J Surv Eng 147(4):04021020

\section{Publisher's Note}

Springer Nature remains neutral with regard to jurisdictional claims in published maps and institutional affiliations.

\section{Submit your manuscript to a SpringerOpen ${ }^{\circ}$ journal and benefit from:}

- Convenient online submission

- Rigorous peer review

- Open access: articles freely available online

- High visibility within the field

Retaining the copyright to your article

Submit your next manuscript at $\boldsymbol{\nabla}$ springeropen.com 